\title{
Trends and regional distributions of land and ocean carbon sinks
}

\author{
J. L. Sarmiento ${ }^{1}$, M. Gloor ${ }^{2}$, N. Gruber ${ }^{3}$, C. Beaulieu ${ }^{1}$, A. R. Jacobson ${ }^{4}$, S. E. Mikaloff Fletcher ${ }^{1, *}$, S. Pacala ${ }^{5}$, and \\ K. Rodgers ${ }^{1}$ \\ ${ }^{1}$ Atmospheric and Oceanic Sciences Program, Princeton University, Princeton, New Jersey, USA \\ ${ }^{2}$ Earth and Biosphere Institute and School of Geography, Leeds University, Leeds, UK \\ ${ }^{3}$ Environmental Physics, Institute of Biogeochemistry and Pollutant Dynamics, ETH Zurich, Zurich, Switzerland \\ ${ }^{4}$ NOAA Earth System Research Lab, Global Monitoring Division, Boulder, Colorado, USA \\ ${ }^{5}$ Department of Ecology and Evolutionary Sciences, Princeton University, Princeton, New Jersey, USA \\ * now at: the National Institute of Water and Atmospheric Research, Wellington, New Zealand
}

Received: 30 October 2009 - Published in Biogeosciences Discuss.: 12 November 2009

Revised: 5 July 2010 - Accepted: 12 July 2010 - Published: 6 August 2010

\begin{abstract}
We show here an updated estimate of the net land carbon sink (NLS) as a function of time from 1960 to 2007 calculated from the difference between fossil fuel emissions, the observed atmospheric growth rate, and the ocean uptake obtained by recent ocean model simulations forced with reanalysis wind stress and heat and water fluxes. Except for interannual variability, the net land carbon sink appears to have been relatively constant at a mean value of $-0.27 \mathrm{Pg} \mathrm{C} \mathrm{yr}^{-1}$ between 1960 and 1988, at which time it increased abruptly by -0.88 ( -0.77 to -1.04$) \mathrm{Pg} \mathrm{Cyr}^{-1}$ to a new relatively constant mean of $-1.15 \mathrm{Pg} \mathrm{C} \mathrm{yr}^{-1}$ between 1989 and 2003/7 (the sign convention is negative out of the atmosphere). This result is detectable at the $99 \%$ level using a t-test. The land use source (LU) is relatively constant over this entire time interval. While the LU estimate is highly uncertain, this does imply that most of the change in the net land carbon sink must be due to an abrupt increase in the land sink, LS = NLS $-\mathrm{LU}$, in response to some as yet unknown combination of biogeochemical and climate forcing. A regional synthesis and assessment of the land carbon sources and sinks over the post 1988/1989 period reveals broad agreement that the Northern Hemisphere land is a major sink of atmospheric $\mathrm{CO}_{2}$, but there remain major discrepancies with regard to the sign and magnitude of the net flux to and from tropical land.
\end{abstract}

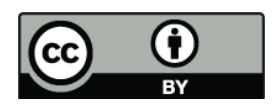

Correspondence to: J. L. Sarmiento (jls@ princeton.edu)

\section{Introduction}

Between 1960 and 2007, the increase in atmospheric $\mathrm{CO}_{2}$ concentration is equivalent to $56 \%$ of the cumulative fossil fuel and cement emissions of $257 \mathrm{Pg} \mathrm{C}$ (Boden et al., 2009), and oceanic uptake of $\mathrm{CO}_{2}$ as estimated by models forced with the observed atmospheric $\mathrm{CO}_{2}$ is equivalent to $\sim 33 \%$. The remaining $\sim 11 \%$ of the fossil fuel and cement emissions are generally assumed to have been taken up by the terrestrial biosphere (the net land carbon sink or NLS), with various sink mechanisms (the land carbon sink or LS) presumed to exceed the sources due to land use changes such as tropical deforestation. Estimates of these numbers and their trends in time have remained remarkably consistent over time (e.g., Broecker et al., 1979) although our confidence in them, particularly in estimates of the oceanic uptake (cf. Gruber et al., 2009) has greatly improved. By contrast, pinning down the net terrestrial biosphere contribution to the carbon budget, NLS = LS+LU (where LU is land use sources), and determining the causes of LS and developing the ability to predict how LS (and the ocean carbon sink) will behave in the future, are among the enduring problems in carbon cycle research.

This study is motivated by two results from the literature that raise important questions regarding the atmospheric $\mathrm{CO}_{2}$ growth rate and the land carbon sink. The first is the evidence from land carbon models that LS may already be decreasing in response to climate change (see the recent review by Le Quéré et al., 2009). Although the decrease is small, and there is great disagreement between models, Le Quéré et al. (2009), suggest that the increase in the observed airborne fraction (the ratio of the annual atmospheric growth rate to the annual fossil fuel plus land use emissions) over the past decades may in fact be a signal that climate is already

Published by Copernicus Publications on behalf of the European Geosciences Union. 
beginning to negatively impact the land (and ocean) carbon sinks (cf. Canadell et al., 2007). We show in Gloor et al. (2010) that although the changes in the airborne fraction that would be expected from the model based estimates of the impact of climate on LS are detectable at the $90 \%$ level, it is not possible to determine with any confidence whether the observed changes in this quantity are due to a change in the efficiency of the carbon sinks (which Gloor et al. define as the fraction of the excess $\mathrm{CO}_{2}$ in the atmosphere that is removed per unit time) or if it rather reflects changes in the sources over time. In this paper, we provide an alternative view of the temporal behavior of the land carbon sink based on an analysis of NLS as estimated from the difference between estimated fossil fuel emissions minus observations of the atmospheric $\mathrm{CO}_{2}$ growth rate and model/data based estimates of oceanic uptake, and then of LS = NLS - LU.

The second result that motivated this study was the finding by Phillips et al. (1998), Chave et al. (2008), Phillips et al. (2009), and Lewis et al. (2009), based on regular forest censuses, that there appears to be a very large contemporary terrestrial carbon sink in mature tropical forests, large enough indeed to approximately balance the estimated tropical deforestation source. While the net zero flux in the tropical land regions implied by these results is within the range of uncertainty of many atmospheric inversion studies (cf. Denman et al., 2007; and further discussion below), such inverse studies also obtain estimates of the air-sea flux that are inconsistent with our best knowledge of the ocean carbon cycle (cf. Gruber et al., 2009). Jacobson et al. (2007a,b) were able to reconcile the atmospheric constraints with the oceanic observations in a joint atmosphere-ocean inverse. However, when they did this, they found a large net carbon loss to the atmosphere in tropical land regions that was approximately equal to the deforestation source. This implied that there was no significant $\mathrm{CO}_{2}$ tropical carbon sink outside the areas impacted by deforestation, contrary to the results from in situ measurements. In this study, we revisit the regional carbon flux estimates, examining "bottom-up" estimates of land carbon fluxes, that is those based on ecosystem measurements and process-based models; and "top-down" estimates, that is those based on atmospheric and joint atmosphere-ocean inverse studies; and the consistency of these with the results obtained from our analysis of the global carbon budget.

We begin in the next section by summarizing the global carbon budget for the period between 1960 and 2007, considering first the best-known components of the carbon cycle, which are the atmospheric $\mathrm{CO}_{2}$ growth rate and fossil fuel emissions. We then show five model-based estimates of the next best-known component of the carbon budget, oceanic uptake, and finally estimate the net land carbon sink by subtracting the atmospheric $\mathrm{CO}_{2}$ growth rate and estimated oceanic uptake from the fossil fuel emissions.

\section{Global carbon budget, 1960 to 2007}

See Appendix A for a description of the data sources and analysis methods used in preparing the figures and tables presented in this section. By convention, a sink of $\mathrm{CO}_{2}$ is reported as negative (removing $\mathrm{CO}_{2}$ from the atmosphere) and a source as positive (adding $\mathrm{CO}_{2}$ to the atmosphere)

\subsection{Fossil fuel emissions}

Figure 1a shows the fossil fuel and cement production emissions estimates that we use for our carbon budget (Boden et al., 2009; updated through 2008 by Marland, personal communication, 2009). Fossil fuel burning increased at a rate of $4.0 \%$ per year for two decades between 1960 and 1979, before dropping to $1.0 \%$ per year for the next two decades. The growth rate surged to $3.8 \%$ per year over the past six years from 2002 to the end of the data set in 2008 (cf. Raupach et al., 2007), but is expected to level off or decrease in 2009 because of the economic recession (Le Quéré et al., 2009). The uncertainty of the fossil fuel emissions is considered to be about $\pm 6 \%$ (Marland, 2008). Of particular concern for our trend analysis are systematic errors, such as the recent reduction in the liquid fuel emission estimates starting in 1977 (Boden et al., 2009). However, this particular revision turned out to be too small to impact our results in a significant manner.

\subsection{Atmospheric $\mathrm{CO}_{2}$ increase}

Model simulations and comparisons between observations at various locations around the world show that the annual growth rate of atmospheric $\mathrm{CO}_{2}$ measured at Mauna Loa is representative of the global growth rate with an estimated standard deviation of $\pm 0.26 \mathrm{ppm} \mathrm{yr}^{-1} \quad\left( \pm 0.55 \mathrm{PgC} \mathrm{yr}^{-1}\right.$; Dr. Pieter Tans, NOAA/ESRL, www.esrl.noaa.gov/gmd/ ccgg/trends/). The longest nearly continuous record of this concentration is that of Keeling et al. (2001). Figure 1a shows the deseasonalized monthly rate of increase of atmospheric $\mathrm{CO}_{2}$ from that data set through 2008. Given the major influence of fossil fuel emissions on the atmosphere, one would expect the atmospheric $\mathrm{CO}_{2}$ growth rate to increase in conjunction with the increase in fossil fuel emissions, as it does. However, the growth rate of atmospheric $\mathrm{CO}_{2}$ has been exceedingly variable (Fig. 1a). This variability is highly correlated with the El Niño/Southern Oscillation, which is the globally dominant mode of climate variability. Analysis of atmospheric transport models and observations suggests that the variability results primarily from terrestrial processes (Peylin et al., 2005; Baker et al., 2006), with the greater part attributed to the tropics, split evenly between Asia and the combined Africa/South America land region (Baker et al., 2006). In general, the land biosphere loses carbon to the atmosphere during warm climate El Niño events and increases carbon uptake during cold climate La Niña and 

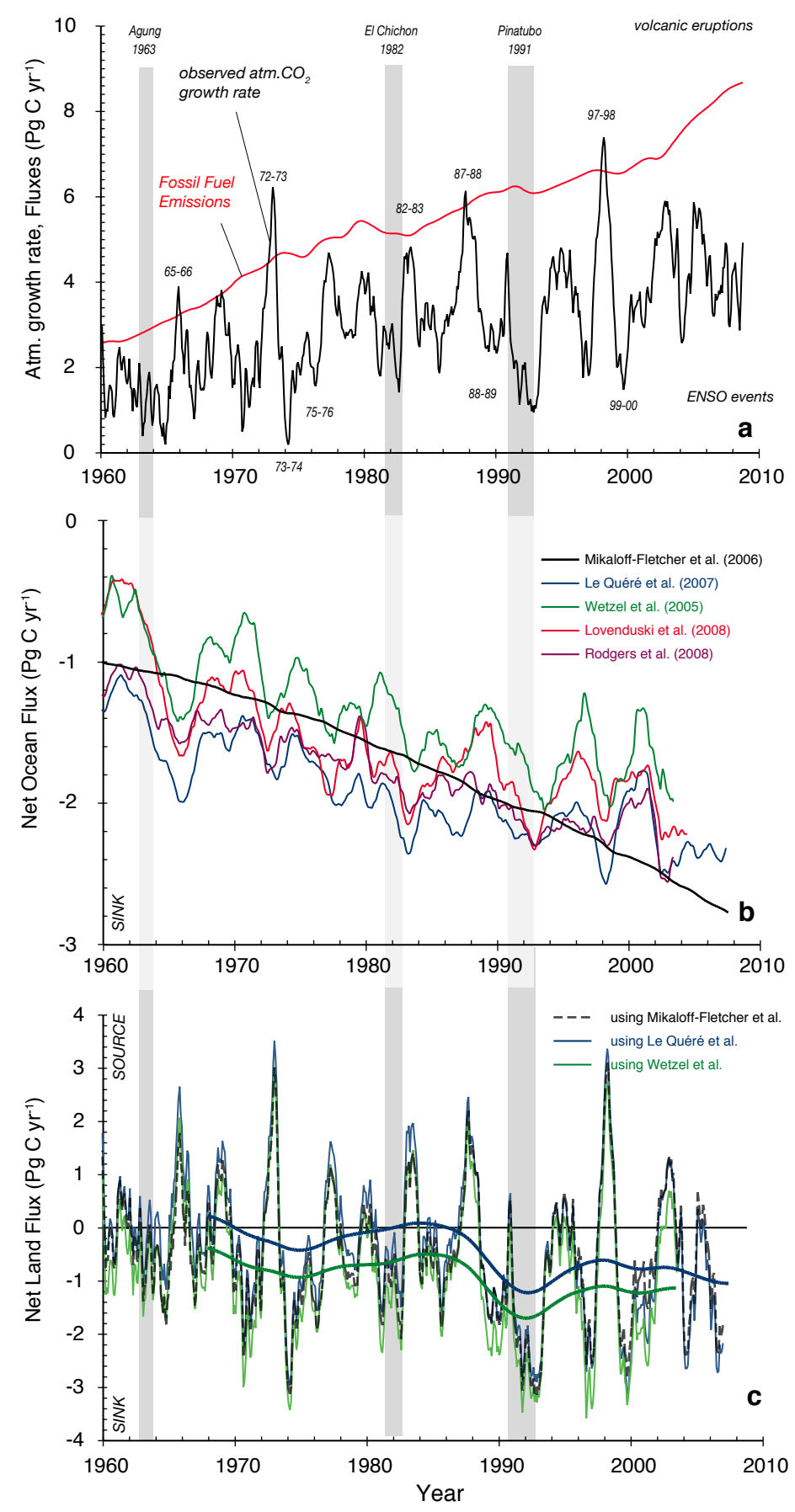

Fig. 1. Monthly deseasonalized carbon fluxes in $\mathrm{PgC}_{\mathrm{Cr}}{ }^{-1}$. (a) Fossil fuel emissions and annual atmospheric growth rate calculated with Mauna Loa data (see Appendix A for data sources and methods). Major volcanic eruptions and ENSO events are identified by their dates. (b) Net atmosphere-ocean fluxes of $\mathrm{CO}_{2}$ as simulated by ocean models. The solid black line labeled Mikaloff Fletcher et al. (2006) represents the expected temporal evolution of the ocean uptake if there is no change in ocean circulation and transport. By construction, this goes through our best data and model based estimates of ocean $\mathrm{CO}_{2}$ uptake of $\sim 2.2 \pm 0.2 \mathrm{Pg} \mathrm{C} \mathrm{yr}^{-1}$ for the 1990s and early 2000s (cf. Gruber et al., 2009). The Le Quéré et al. (2007), Lovenduski et al. (2008), Rodgers et al. (2008) and Wetzel et al. (2005) results are from ocean "hindcast" simulations, where an ocean carbon cycle model is forced with re-analyzed variations of wind, and freshwater and heat fluxes over the last few decades. The Le Quéré et al., Rodgers et al., and the Lovenduski et al. simulations all overlap the Mikaloff Fletcher et al. result during the 1990s. The Wetzel et al. ocean carbon sink estimate is somewhat on the low side, though its behavior in time, which is the aspect of these models that we emphasize in the discussion, is similar to that of the others. (c) Net atmosphere-land fluxes of $\mathrm{CO}_{2}$ estimated by subtracting three model estimates of the ocean sink from panel (b) and the atmospheric $\mathrm{CO}_{2}$ growth rate from panel (a) from the fossil fuel emissions shown in panel (a). The smooth lines are from a Butterworth filter with a five year smoothing time scale. 
volcanic eruption events, particularly during and after the Mt. Pinatubo eruption of June 1991 (Jones and Cox, 2001; Roderick et al., 2001; Gu et al., 2003; Peylin et al., 2005;). The ocean usually has an opposite impact on the observed atmospheric $\mathrm{CO}_{2}$ growth rate due to the suppression of Equatorial $\mathrm{CO}_{2}$ outgassing during $\mathrm{El}$ Niño resulting from reduced upwelling of carbon, with the opposite occurring during $\mathrm{La}$ Niña events (Feely et al., 2006). However, this effect is much smaller than the land effect.

\subsection{Oceanic $\mathrm{CO}_{2}$ uptake}

A recent set of ocean carbon cycle models has been developed with the goal of simulating the time-varying nature of ocean circulation over the last few decades by forcing with wind and heat and water fluxes from reanalysis of observed meteorological fields (Wetzel et al., 2005; Le Quéré et al., 2007, 2009; Lovenduski et al., 2008; Rodgers et al., 2008). The subset of these simulations shown in Fig. 1b suggest that starting in the mid to late-1980's there was a leveling off of oceanic $\mathrm{CO}_{2}$ uptake (Fig. 1b). This came as something of a surprise, since previous simulations with both steady-state ocean models and coupled climate models forced with the observed $\mathrm{CO}_{2}$ had predicted that ocean uptake should have increased over this time period. As an example of such models, we show in Fig. $1 b$ the results of a ten-model ocean inversion designed to estimate surface carbon fluxes consistent with ocean interior data from the global ocean carbon survey of the 1990s (Mikaloff Fletcher et al., 2006). As the models underlying this inversion were forced with a climatic average of seasonally varying winds and heat and water fluxes, the estimated surface carbon fluxes reflect a climatologicalmean uptake and vary only in response to the increase in atmospheric $\mathrm{CO}_{2}$.

As regards the location and mechanisms of the reduced oceanic $\mathrm{CO}_{2}$ uptake simulated by the models, a large portion of it occurs in the Southern Ocean, where an intensification of winds over time leads to increased upwelling of waters rich in pre-anthropogenic dissolved inorganic carbon (DIC) that is then released to the atmosphere as $\mathrm{CO}_{2}$ (Wetzel et al., 2005; Le Quéré et al., 2007; Lovenduski et al., 2007, 2008). The enhanced upwelling also accelerates the uptake of anthropogenic $\mathrm{CO}_{2}$, but this effect is smaller (Lovenduski et al., 2008). Taken together, these changes in wind forcing reduce the Southern Ocean net sink for atmospheric $\mathrm{CO}_{2}$. Climate model simulations are able to reproduce a similar intensification of the winds resulting from a combination of increased greenhouse gases and stratospheric ozone depletion (cf. Thompson and Solomon, 2002; Chen and Held, 2007; Lenton et al., 2009). Ongoing studies are analyzing the trends in ocean model regions outside the Southern Ocean as well as the sensitivity of ocean models to forcing with other reanalysis products.

Time series observations of air-sea $\mathrm{CO}_{2}$ fluxes are extremely limited, but there is evidence from 23 years of ob- servations in the Equatorial Pacific of an increase in the outgassing flux of $0.09 \pm 0.16 \mathrm{Pg} \mathrm{C} \mathrm{yr}^{-1}$ after the Pacific Decadal Oscillation regime shift of 1997-1998 (Feely et al., 2006). There is also evidence of a decline of $0.24 \pm 0.1 \mathrm{Pg} \mathrm{C} \mathrm{yr}^{-1}$ in $\mathrm{CO}_{2}$ uptake in the North Atlantic between $20^{\circ} \mathrm{N}$ and $65^{\circ} \mathrm{N}$ sometime during the period between 1994/1995 and 2002-2005 (Schuster and Watson, 2007). By contrast, in the North Pacific, the observed rate of increase of surface ocean $p \mathrm{CO}_{2}$ over a 35 year period lags the atmospheric growth rate slightly (though the difference in growth rates is not statistically significant), and in the Bering Sea and periphery of the Sea of Okhotsk, the surface ocean $p \mathrm{CO}_{2}$ has actually decreased over time (Takahashi et al., 2006), suggesting that in this region the uptake may have increased over time. Furthermore, observations from the Hawaii Ocean Time series (HOT) and Bermuda-Atlantic Time series (BATS) stations show little evidence of a long-term trend in the air-sea gradient of $\mathrm{CO}_{2}$ (e.g. Gruber et al., 2002; Keeling et al., 2004; Bates, 2007; Dore et al., 2009). The observational analyses and model results thus suggest that the decline in oceanic uptake, if it stands up to continued investigation, is likely a complex global scale phenomenon that alters the current distribution of oceanic sources and sinks, and that it involves changes in both the "natural" carbon cycle that existed before the Anthropocene as well as to the rate of uptake of the anthropogenic perturbation per se.

\subsection{Net land sink}

Figure 1c shows our global carbon budget estimate of the annual net fluxes of $\mathrm{CO}_{2}$ between the atmosphere and the land biosphere calculated by taking the difference between fossil fuel emissions and the annual atmospheric growth rate and oceanic uptake. Since these land fluxes are computed by difference, it is important to have in mind that they also reflect errors in the component sources and sinks that go into the calculation. Three estimates are shown based on the ocean models from Fig. 1b. The estimate using the Mikaloff Fletcher et al. (2006) results are representative of the expected behavior of the net land flux if the ocean circulation had remained constant over time, while the other two estimates represent an upper (Le Quéré et al., 2007) and lower (Wetzel et al., 2005) limit of the inferred increase in net land fluxes if the oceanatmosphere $\mathrm{CO}_{2}$ fluxes change in response to time-varying ocean circulation and biogeochemistry.

The predominant signal in the inferred net land flux of Fig. $1 \mathrm{c}$ is the very large interannual variability. A comparison of Fig. 1a, b, and c shows that most of this interannual variability carries over from the atmospheric growth rate, i.e. much of it is associated with ENSO variability. In addition, it has been shown that cooler than normal episodes associated with explosive volcanic eruptions, such as the Pinatubo eruption in 1991 tend to lead to a negative net land flux, i.e., enhance the net uptake by the land (Jones and Cox, 2001). 
Table 1. The mean of net land uptakes for the periods $1960-1988$ and $1989-2003 / 7$ and the difference $\Delta=1989-2003 / 7$ minus $1960-$ 1988 using each of the ocean models shown in Fig. 1b. The net land uptake numbers are calculated from the annual means to remove the autocorrelation.

\begin{tabular}{rrcrl}
\hline & $1960-1988$ & $1989-2003 / 7$ & $\Delta$ & $p^{\mathrm{b}}$ \\
Reference ocean model $^{\mathrm{a}}$ & -0.32 & -0.96 & $-0.64 \pm 0.30$ & $0.02^{*}$ \\
\hline Le Quéré et al. (2007) & 0.04 & -1.01 & $-1.04 \pm 0.31$ & $0.00^{* *}$ \\
Lovenduski et al. (2008) & -0.45 & -1.34 & $-0.89 \pm 0.32$ & $0.00^{* *}$ \\
Rodgers et al. (2008) & -0.13 & -0.90 & $-0.77 \pm 0.32$ & $0.01^{* *}$ \\
Wetzel et al. (2005) & -0.54 & -1.36 & $-0.83 \pm 0.34$ & $0.01^{* *}$ \\
MEAN & -0.27 & -1.15 & -0.88 & \\
\hline
\end{tabular}

\footnotetext{
${ }^{a}$ Reference ocean model is the ocean uptake and net land uptake calculated using the constant climate ocean inverse model result of Mikaloff Fletcher et al. (2006).

${ }^{\mathrm{b}} p$ is the $p$-value. The null hypothesis that the 1960-1988 mean is equal to the 1989-2003/7 mean is tested against the alternative that the 1960-1988 mean is smaller than the 1989-2003/7 mean using a t-test. The $p$-value is the probability, under the null hypothesis, of observing a value at least as extreme as the observed test statistic. The smaller the $p$-value, the more significant the test is.

* Significant at $5 \%$ critical level (or $95 \%$ confidence level).

** Significant at $1 \%$ critical level (or $99 \%$ confidence level).
}

Despite the magnitude of the variability, it is possible to note a tendency for the net land fluxes to be more negative after 1988/1989 than before, reflecting a stronger sink. We show in Fig. 2 the cumulative net land uptake estimated from 1960 onwards. Cumulative distribution plots such as this are a useful way of low-pass filtering observations, provided one has in mind that the smoothing is progressively greater as one goes from the early part of the record when the cumulative flux is small to the latter part of the record where it becomes much larger. In a diagram such as this, a line with a constant slope implies a constant land flux. If the land carbon sink were increasing with time, as might be expected if the land uptake were due to $\mathrm{CO}_{2}$ fertilization, the cumulative land inventory would be concave downwards, unless the fertilization effect became saturated. This view of the data suggests that the net land flux varied about a relatively constant mean before 1988/1989, and that it varied about a higher mean after 1988/1989. The climate impact of the Pinatubo eruption led to a large increase in the net land carbon inventory between 1991 and 1993, after which the cumulative land carbon inventory settled back again, but continued to increase at a faster pace (steeper slope) than before 1988/1989. In other words, not only does the $\mathrm{CO}_{2}$ uptake of the Pinatubo era appear to have been retained by the land, but it also appears that the land shifted to a higher overall uptake rate than before, possibly beginning in 1988/1989, before the Pinatubo eruption.

The net land sink estimated using the four time-varying ocean models of Fig. 1b increases by an average of -0.88 $(-0.77$ to -1.04$) \mathrm{PgC} \mathrm{yr}^{-1}$ ( $p$-value $=0.00$ to 0.01 ) from -0.27 (0.04 to -0.54$) \mathrm{Pg} \mathrm{C} \mathrm{yr}^{-1}$ before the $1988 / 1989$ bend in the cumulative uptake to -1.15 ( -0.90 to -1.36$)$ thereafter (see Table 1). Without the years of maximum Pinatubo

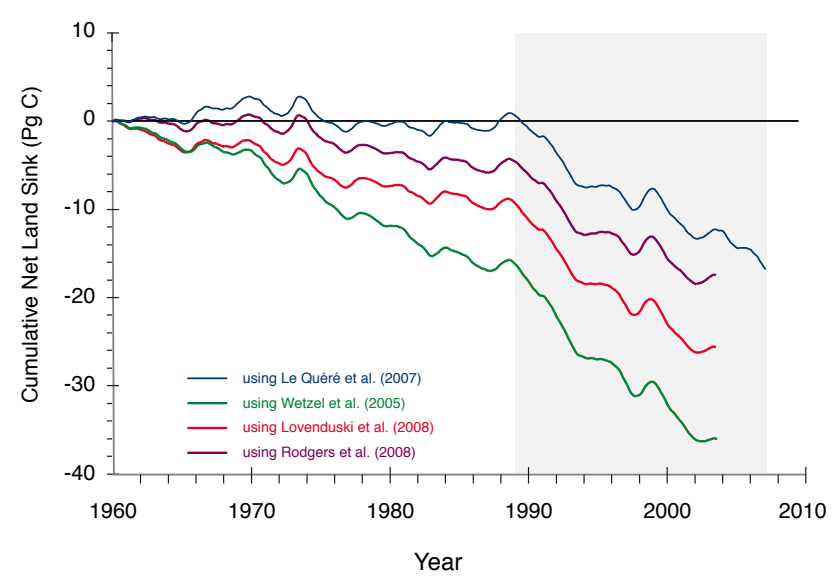

Fig. 2. Cumulative net land uptake starting from 1960 calculated from the results in Fig. 1c.

impact in 1991-1993, the increase is still quite large, -0.72 $(-0.56$ to -0.92$) \mathrm{PgC} \mathrm{yr}^{-1}$ ( $p$-value $=0.00$ to 0.05 ). An increase in the net land carbon sink such as we observe had been noted previously for the 1990s relative to the 1980s (Schimel et al., 2001). However, our analysis suggests that there may have been a much greater persistence in time of this signal, including that the major Pinatubo anomaly of 1991 to 1993 can account for only $-0.17(-0.12$ to -0.21$) \mathrm{PgC} \mathrm{yr}^{-1}$ of the $-0.88 \mathrm{Pg} \mathrm{Cyr}^{-1}$ increase in our long-term averages. 
Table 2. Mean of ocean uptakes in the ocean models in Fig. 1b for the periods 1960-1988 and 1989-2003/7 and the difference $\Delta=1989-$ 2003/7 minus 1960-1988. Only the reference model and Le Quéré et al. (2007) models were run out to 2007, The Wetzel et al. (2005) model was run out to 2003, and the Rodgers et al. (2008) and Lovenduski et al. (2008) models were run out to 2004 (see Appendix A). Also shown is $\Delta_{\text {Model X-Reference }}=1989-2003 / 7$ average minus 1960-1988 average of the year-by-year difference between each model (Model X) minus the reference constant climate model of Mikaloff Fletcher et al. (2006). The mean ocean uptakes are calculated using the annual mean ocean uptake to remove the autocorrelation.

\begin{tabular}{rcccccc}
\hline & $1960-1988$ & $1989-2003 / 7$ & $\Delta$ & $p^{\mathrm{b}}$ & $\Delta_{\text {Model X-Reference }}^{\mathrm{c}}$ & $p^{\mathrm{b}}$ \\
Reference ocean model $^{\mathrm{a}}$ & -1.41 & -2.36 & $-0.95 \pm 0.08$ & $0.00^{*}$ & & \\
\hline Le Quéré et al. (2007) & -1.77 & -2.20 & $-0.44 \pm 0.07$ & $0.00^{*}$ & $0.49 \pm 0.07$ & $0.00^{*}$ \\
Lovenduski et al. (2008) & -1.28 & -1.80 & $-0.51 \pm 0.10$ & $0.00^{*}$ & $0.34 \pm 0.09$ & $0.00^{*}$ \\
Rodgers et al. (2008) & -1.60 & -2.16 & $-0.57 \pm 0.07$ & $0.00^{*}$ & $0.26 \pm 0.05$ & $0.00^{*}$ \\
Wetzel et al. (2005) & -1.19 & -1.70 & $-0.51 \pm 0.08$ & $0.00^{*}$ & $0.32 \pm 0.08$ & $0.00^{*}$ \\
MEAN & -1.46 & -1.97 & -0.51 & - & 0.35 & - \\
\hline
\end{tabular}

a Reference ocean model is the ocean uptake and net land uptake calculated using the constant climate ocean inverse model result of Mikaloff Fletcher et al. (2006).

b $p$ is the $p$-value. The null hypothesis that the 1960-1988 mean is equal to the 1989-2003/7 mean is tested against the alternative that the 1960-1988 mean is smaller than the 1989-2003/7 mean using a t-test. The $p$-value is the probability, under the null hypothesis, of observing a value at least as extreme as the observed test statistic. The smaller the $p$-value, the more significant the test is.

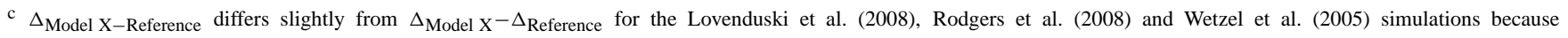
$\Delta_{\text {Model X-Reference }}$ is calculated only over the period covered by the Model X simulations (2003 for Wetzel et al. and Rodgers et al.; 2004 for Lovenduski et al.).

* Significant at $1 \%$ critical level (or $99 \%$ confidence level).

\subsection{Uncertainties and implications of global carbon budget analysis}

We emphasize that our estimate of the net land uptake is calculated as the difference between fossil fuel emissions, the atmospheric growth rate, and the oceanic uptake. The requirement for an increase in the net land carbon sink of -0.88 ( -0.77 to -1.04$) \mathrm{Pg} \mathrm{C} \mathrm{yr}^{-1}$ after $\sim 1988 / 1989$ arises from the fact that the atmosphere and ocean in combination are taking up a smaller portion of the fossil fuel emissions than they were prior to $1988 / 1989$, which means that the land must account for more. The range in these estimates comes just from the range in ocean model simulations, not including uncertainties in fossil fuel emissions and the atmospheric growth rate. We noted earlier that the uncertainty in fossil fuel emissions is estimated as $\pm 6 \%$, which puts it in the same ballpark as the uncertainty in the atmospheric growth rate of $\pm 0.55 \mathrm{Pg} \mathrm{C} \mathrm{yr}^{-1}$. We present here the average of the fossil fuel emissions and atmospheric growth rate estimates over a period of 14 to 28 years. Treating each year of data as independent gives an uncertainty of the mean fossil fuel emissions and atmospheric growth rate that is a factor of $\sqrt{14}$ to $\sqrt{28} \approx 4$ to 5 smaller than the error of the individual measurements, i.e., $\pm 0.1 \mathrm{PgC} \mathrm{yr}^{-1}$, which is comparable to the range obtained by the ocean models.

What can we say about the uncertainty in the ocean carbon sink and its change over time? We can estimate the reduction in the oceanic carbon sink after 1988/1989 as follows: the 1989-2003/7 mean sink estimated by the constant climate ocean inversion shown in Fig. $1 \mathrm{~b}$ and Table 2 is higher by
-0.95 than the mean sink between 1960 and 1988. As Fig. 3 and Table 2 show, the average increase in the oceanic sink for the 1989-2003/7 period versus the 1960-1988 period by the models that are subject to time-varying forcing is only -0.51 . The difference between these ocean model results show that, on average, the time-varying ocean models take up 0.35 (0.26 to 0.49) $\mathrm{Pg} \mathrm{C} \mathrm{yr}^{-1}$ less $\mathrm{CO}_{2}$ between 1989 and $2003 / 7$ than they would have if ocean circulation and biogeochemistry had remained constant. The changes that we show in Table 2 are detectable at the $99 \%$ confidence level for each model simulation. However, this statistical analysis takes into consideration only the strength of the signal and the variability as predicted by each model individually as compared to the Mikaloff Fletcher et al. (2006) ocean inversion. Other potential sources of error include:

1. The use of different ocean circulation and biogeochemical models. The range in our four model results, 0.26 to $0.49 \mathrm{Pg} \mathrm{C} \mathrm{yr}^{-1}$, gives some idea of how large this source of uncertainty is likely to be.

2. The baseline constant climate scenario. A more appropriate way to simulate the baseline constant climate scenario would be to do this separately for each model. This has now been done for a set of 4 models as summarized by Le Quéré et al. (2009) and the post-1988/1989 minus pre-1988/1989 difference that we calculate from the average of their 4 models is $0.26 \pm 0.05 \mathrm{Pg} \mathrm{C} \mathrm{yr}^{-1} \mathrm{de}-$ tectable at the $99 \%$ confidence level. This is within the range of our estimates. 


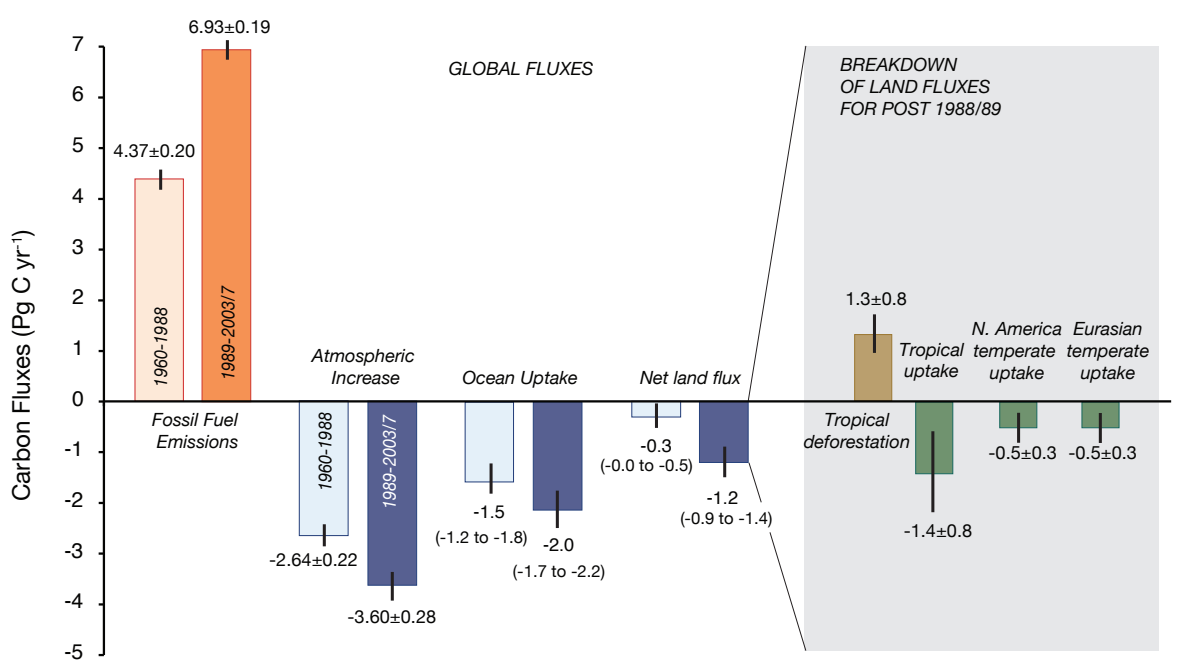

Fig. 3. Global flux estimates for 1960 to 1988 and 1989 to 2003/7 obtained by averaging the fluxes shown in Fig. 1 and Table 2 . The shaded region on the right summarizes the post-1988/1989 bottom-up land source and sink components discussed in the text.

3. Sensitivity to the reanalysis product used to force the ocean models and whether the atmospheric forcing fields represent skillfully decadal variations in the state of the atmosphere. The Le Quére et al. (2009) supplementary material shows a series of ocean model simulations with different reanalysis products that appear to indicate only minor differences, but this issue needs further examination.

4. Whether the models are simulating oceanic variability correctly. While observational constraints on this are limited, there are some observations discussed above; and model studies such as those referenced earlier (cf. also Doney et al., 2009) tend to show that models overall do a reasonable job of simulating observed variability.

5. Whether the models have all the correct physical processes. In particular additional model studies are needed to examine the extent to which eddy transfer in the ocean may in fact cancel some of the effects of increased wind-driven Ekman divergence in the Southern Ocean (cf. Hallberg and Gnanadesikan, 2006; Böning et al., 2008). It is currently an area of active research to determine whether the mesoscale parameterization used in the global models represented in Fig. 1b is adequate to represent the effect of eddy transfer found in higher resolution models.

Our analysis suggests that the oceanic carbon uptake lagged the growth that would have been expected if ocean circulation and biogeochemistry had remained constant by about 0.35 (0.26 to 0.49) $\mathrm{Pg} \mathrm{C} \mathrm{yr}^{-1}$ after 1988/1989. Summing our estimated reduction in oceanic uptake to the increase in net land uptake of -0.88 ( -0.77 to -1.04$) \mathrm{Pg} \mathrm{Cyr}^{-1}$ gives an estimated reduction in the atmospheric growth rate of -0.53 $(-0.51$ to -0.55$){\mathrm{PgC} \mathrm{yr}^{-1}}^{-1}$. The uncertainty in these estimates is large, particularly when one considers the additional uncertainty of order $\pm 0.1 \mathrm{Pg} \mathrm{C} \mathrm{yr}^{-1}$ contributed by the fossil fuel emissions and atmospheric growth rate. However, if they hold up to further scrutiny, the implications for the land carbon sink are dramatic given that they represent more than a quadrupling of the net land carbon sink and a 50\% increase in the absolute magnitude of the total annual land carbon sink since 1960 (see discussion in Sect. 4). The implied reduction in atmospheric growth rate would be a challenge to detect, because it is relatively small compared to the observed growth rate and its interannual variability.

How consistent is this ocean model-based partitioning between the land and ocean with other, independent constraints, such as those based on measurements of carbon- 13 in the ocean and atmosphere or of the atmospheric $\mathrm{O}_{2} / \mathrm{N}_{2}$ ratio (e.g. Battle et al., 2000; Bender et al., 2005; Manning and Keeling, 2006)? Given the uncertainties in our knowledge of carbon isotope fractionations and the small magnitude of the change in the net land carbon sink relative to the interannual variability, it is unlikely that the signal resulting from such a change in the land carbon sink could be detected in carbon isotope measurements. The $\mathrm{O}_{2} / \mathrm{N}_{2}$ tracer is more promising, but measurements were not initiated until after the change in the net land carbon sink occurred and the uncertainties in the land uptake estimates based on this tracer are very large. Our post-1988/1989 net land uptake estimate of -1.15

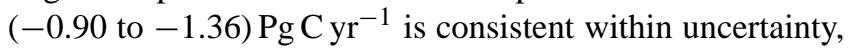
though at the upper limit of the atmospheric oxygen based estimate of $-0.51 \pm 0.74 \mathrm{Pg} \mathrm{C} \mathrm{yr}^{-1}$ obtained for the period of 1993 to 2003 by Manning and Keeling (2006). A possible implication of our result is that Manning and Keeling may have overestimated the magnitude of the correction for the 
outgassing of oxygen due to warming of the ocean. Without this degassing, their estimate of the land carbon sink would be $-0.99 \mathrm{Pg} \mathrm{C}_{\mathrm{yr}}{ }^{-1}$.

\section{Regional land carbon flux distribution after 1988/1989}

We turn now to a discussion of the regional distribution of the land carbon source and sink components to examine their consistency with our global carbon budget estimates of the net carbon flux and see what clues such estimates may offer as to the cause of the acceleration in the net terrestrial uptake and its spatial distribution (see gray area in Fig. 3). We begin with bottom-up estimates based on in situ measurements and models, then proceed to a discussion of top-down estimates based on inverse models.

\subsection{Bottom-up estimates}

The main terrestrial source of $\mathrm{CO}_{2}$ to the atmosphere is tropical land use change (mainly deforestation), which has variously been estimated as either $\sim 1.1 \pm 0.3 \mathrm{Pg} \mathrm{C} \mathrm{yr}^{-1}$ based on analyses of satellite observations (Achard et al., 2002, 2004; DeFries et al., 2002) for the 1980s and 1990s, or $\sim 2.2 \pm 0.6 \mathrm{Pg} \mathrm{C} \mathrm{yr}^{-1}$ from "bookkeeping" methods based on FAO expert opinion and official governmental estimates from the 1990s (Houghton, 2003; cf., Food and Agriculture Organization, 2001; Fearnside, 2000). (Bookkeeping methods track the amount of carbon released to the atmosphere from clearing and decay of plant material, plus the amount of carbon accumulated as vegetation grows back.) However, more recently, Houghton (2007) revised his bookkeeping estimates down to $\sim 1.5 \pm 0.8 \mathrm{Pg} \mathrm{Cyr}^{-1}$ for the period between 1960 and 2006. This includes an estimate of non-tropical land use change, but the non-tropical component is $<4 \%$ after $1988 / 1989$. The reduction in uptake is due primarily to revised FAO tropical land use change estimates (R. Houghton, personal communication, 2009; note, however, that the reliability of FAO inventories is unclear; Grainger, 2008). In addition, there are some new estimates by Shevliakova et al. (2009) that combine the bookkeeping and satellite methods, giving estimates that are as low as $1.1 \mathrm{PgC} \mathrm{yr}^{-1}$ over this time interval. In what follows, we will use for our estimate of the tropical land use change source the median of these new estimates, $1.3 \mathrm{Pg} \mathrm{C} \mathrm{yr}^{-1}$ with a nominal uncertainty of $\pm 0.8{\mathrm{PgC} \mathrm{yr}^{-1}}^{\text {. }}$.

Bottom-up estimates of land carbon sinks are only available for the post-1988/1989 period. The most complete inventory of land carbon sinks is for North America for circa 2003 (Pacala et al., 2007). This shows a net carbon sink of $-0.5 \pm 0.3 \mathrm{PgC} \mathrm{yr}^{-1}$ with $\sim 60 \%$ from the forest sector due to increases in the mean age of forest stands because of relaxed rates of harvest, agricultural abandonment, and fire suppression. The remaining sink is due to other hu- man activities such as construction of dams, the practices of the forest products and waste disposal industries, and accumulation of carbon in wood products and landfills, reservoirs, pasture lands and wetlands. Research is mixed on the role that fertilization by nitrogen or $\mathrm{CO}_{2}$ plays in the North American carbon sink (Pacala et al., 2007). Inventories from Eurasia are less complete, but by augmenting the estimates for the temperate and boreal Eurasian forest sector $(-0.3 \pm 0.1$; Goodale et al., 2002) with the non-forest sector implied by the North American inventory, we arrive at an estimate of $-1.0 \pm 0.5{\mathrm{PgC} \mathrm{yr}^{-1}}^{-}$for the combined north temperate and boreal zones. Both this estimate and its uncertainty must be viewed as tentative. Although estimates from eddy-covariance studies have provided useful local confirmation of the inventory methods (Barford et al., 2001; Pacala et al., 2007), they cannot be used yet to determine average fluxes over large regions (though see Jung et al., 2009). This is because the network of such sites is too small to average accurately over heterogeneity in the physical environment and terrestrial land use, and there continue to be concerns of bias due to the inability to retrieve fluxes during periods of stratification, which occur primarily at night when ecosystems are a net source of $\mathrm{CO}_{2}$.

Carbon inventory measurements in mature tropical forests are far less extensive than temperate inventory estimates. Measurements of a 60000 -tree network across Amazonia indicates that primary forest gained carbon during the 1990's at an average rate of $-0.8 \pm 0.3 \mathrm{Pg} \mathrm{Cyr}^{-1}$ (Phillips et al., 2009). Using similar data from fewer but much larger plots from Southeast Asia (6 plots) and Africa (2 plots) (Chave et al., 2008) and the same reasoning as in the Amazonian study by Phillips et al. (1998) to extrapolate these studies spatially, we obtain a total tropical mature forest sink estimate of $-1.4 \pm 0.8 \mathrm{Pg} \mathrm{C} \mathrm{yr}^{-1}$. This number is consistent with the just published study of Lewis et al. (2009) which reports results from 79 plots of $\sim 1$ ha area in Africa, which were combined with growth trends estimated from South American and Asian tropical plots, to obtain a pantropical sink estimate in old-growth forests of $-1.3 \mathrm{Pg} \mathrm{C} \mathrm{yr}^{-1}$ (confidence interval $=-0.8$ to -1.6 ) over the last decades. Whether or not these measurements are sufficiently broad in scope to be representative is being hotly debated in the literature, as is the mechanism (e.g., Malhi et al., 2008). Some have suggested that the pantropical sink is due to growth stimulation in response to a changing environment including elevated $\mathrm{CO}_{2}$, changes in temperature and precipitation, modified insolation or diffuse radiation; while others have argued that it is rather a response to a changing disturbance regime or possibly recovery from a large scale mega-disturbance event or even simply a measurement artifact.

Summing up our bottom-up estimates of the north temperate and boreal terrestrial carbon sinks together with our estimate of the tropical sink, we arrive at a global terrestrial carbon sink estimate of $-2.4 \pm 0.9 \mathrm{Pg} \mathrm{Cyr}^{-1}$ for the post-1988/1989 period. Given our tropical land use source 


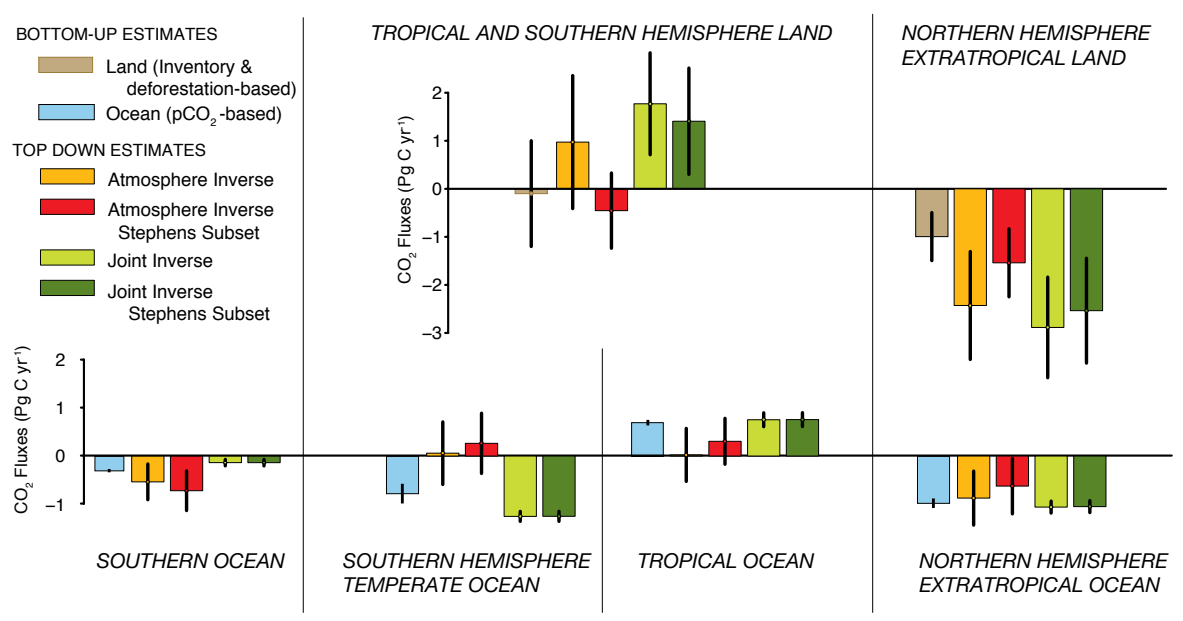

Fig. 4. Regional flux estimates for the land and ocean. The bottom-up land inventory estimates are as described in the text and shown in Fig. 3. The ocean $p \mathrm{CO}_{2}$ based estimates are from Takahashi et al. (2009), the atmosphere inverse results are from the Transcom-3 study of Gurney et al. (2004), the "Atmosphere Inverse Stephens Subset" is from a new atmospheric inverse calculation we did as part of this study using a subset of three of the Transcom-3 atmospheric transport models that provide a better fit to certain criteria based on observed vertical profiles of $\mathrm{CO}_{2}$ in the atmosphere (Stephens et al., 2007), the joint inverse is from Jacobson et al. (2007a), and the "Joint Inverse Stephens Subset" is from a new calculation we did using the Stephens subset of Transcom-3 models. Note that the oceanic data constrain the air-sea flux so strongly that the results of ocean-only inverse studies (e.g., Gruber et al., 2009), i.e., those that do not include the atmospheric constraint used in the joint inverse, give virtually the same answer as the joint inverse. The latitude boundaries used to calculate the ocean uptake are $44^{\circ} \mathrm{S}, 18^{\circ} \mathrm{S}$ and $18^{\circ} \mathrm{N}$.

estimate of $1.3 \pm 0.8 \mathrm{Pg} \mathrm{Cyr}^{-1}$, we obtain a total bottom-up net land sink estimate of approximately $-1.1 \pm 1.2 \mathrm{Pg} \mathrm{C} \mathrm{yr}^{-1}$. This is in very good agreement with our global carbon budget post-1988/1989 net land sink estimate of $-1.15(-0.90$ to -1.36$) \mathrm{Pg} \mathrm{C} \mathrm{yr}^{-1}$ (Table 1 and Fig. 3). These bottom-up estimates of the land carbon sinks and land-use change sources also provide a picture of the regional distribution of carbon sources and sinks, with an estimated net sink of $-1.0 \pm 0.5{\mathrm{PgC} \mathrm{yr}^{-1}}^{-1}$ in the temperate and boreal Northern Hemisphere and a tiny net sink of $-0.1 \pm 1.1 \mathrm{Pg} \mathrm{C} \mathrm{yr}^{-1}$ in the tropics (uptake of $-1.4 \pm 0.8 \mathrm{Pg} \mathrm{C} \mathrm{yr}^{-1}$ minus land use source of $\left.1.3 \pm 0.8 \mathrm{Pg} \mathrm{C} \mathrm{yr}^{-1}\right)$.

We note that while the global carbon budget estimate of Fig. 1c shows that interannual variability of the net land carbon sink is very large $\left( \pm 3 \mathrm{PgC}^{-1}\right)$, the measurements underlying the bottom-up estimates mostly span a long period of time so that the appropriate global carbon budget estimate to compare them with is the long-term average, as we have done (see Fig. 4).

\subsection{Top-down estimates}

Another method to estimate the regional distribution of carbon sources and sinks is the top-down atmospheric inversion method, where a set of regionally resolved ocean-atmosphere and land-atmosphere carbon fluxes are adjusted to be optimally consistent with the observed atmospheric $\mathrm{CO}_{2}$ distribution. One of the most prominent of such studies is the Transcom-3 inversion intercomparison, which used average data for the period between 1992 and 1996 (Gurney et al., 2004; cf. Denman et al., 2007). While this period includes the tail end of the Pinatubo anomaly, the average net land carbon sink over the period is similar to that over the entire period from 1988/1989 to 2007 (cf. Fig. 1c). The Transcom3 inversions obtained a net source of carbon in the tropical and Southern Hemisphere land and a large net sink for carbon in the Northern Hemisphere land (orange bars in Fig. 4).

The uncertainties in the Transcom-3 atmospheric inverse land uptake estimates and the bottom-up land uptake estimates overlap, but there is a rather large offset of $\sim 1 \mathrm{PgC} \mathrm{yr}^{-1}$ between them, with the atmospheric inverse showing a large tropical source where the bottom-up estimates show a near zero flux and the atmospheric inverse showing a much larger sink in the extratropics than the bottom-up estimates. Furthermore, there is a large discrepancy between the air-sea flux estimates obtained by the Transcom-3 atmospheric inversions and independent air-sea flux estimates obtained both by air-sea $p \mathrm{CO}_{2}$ difference measurements combined with a gas exchange model (blue bars in Fig. 4; Takahashi et al., 2009), and by ocean inverse estimates (light green bars; Gruber et al., 2009). The disagreement is particularly striking in the tropical ocean, where the Transcom-3 atmospheric inverse models tend to underestimate the degassing flux relative to the ocean observation based estimates; in the Southern Hemisphere temperate latitudes, where atmospheric inverse models tend to underestimate the uptake relative to the observation based estimates; 
and in the Southern Ocean, where the atmospheric inverse models tend to overestimate the oceanic sink relative to the observation based estimates (cf. Gruber et al., 2009).

The use of ocean interior constraints on air-sea fluxes in a joint atmosphere-ocean inversion ensures that the solution obtained is consistent with the air-sea flux estimates of Jacobson et al. (2007b). However, the land carbon flux solution obtained in this way (light green bar in the upper part of Fig. 4) differs from the terrestrial bottom-up estimates by almost $2 \mathrm{Pg} \mathrm{C} \mathrm{yr}^{-1}$, with the joint inverse giving a much larger source in the tropics and Southern Hemisphere, and a much larger sink in the northern extra tropics than the bottom-up estimates. These are large differences, but unfortunately the uncertainties on the terrestrial flux estimates are so large that the differences are statistically significant at the one standard deviation level only for the Northern Hemisphere extratropics.

An important source of error in atmospheric inversions is the uncertainty in atmospheric transport, which needs to be specified from an atmospheric transport model in order to determine how atmospheric $\mathrm{CO}_{2}$ changes at a particular location in response to fluxes at the surface. The uncertainty in this transport is difficult to quantify and is usually assessed by model intercomparison, as in the Transcom-3 study. In a recent study that made use of new vertical $\mathrm{CO}_{2}$ profiles in the atmosphere (Stephens et al., 2007), only three of the Transcom-3 atmospheric transport models were found to be consistent with the annual mean observed vertical gradients of $\mathrm{CO}_{2}$ in the annual mean (though this was due to a cancellation of errors in the seasonal profiles). However, while this subset of models did change the land fluxes somewhat, in fact bringing them into better agreement with the bottom-up land flux estimates, they compare poorly with the ocean-based flux estimates (Fig. 4). Using these three atmospheric transport models in the joint inverse gives results shown in the dark green bars in Fig. 4 that are similar to the full Transcom3 model suite for air-sea fluxes, with slight changes on land tending to give fluxes that are in slightly better agreement with the bottom-up estimates.

Solving the inconsistencies between the bottom-up and top-down estimates of the regional distribution of land sources and sinks for atmospheric $\mathrm{CO}_{2}$ has to comprise all four of the following: (1) improved bottom-up land carbon flux estimates including particularly carbon inventory measurements with improved measurements of soil carbon inventory; (2) incorporating the new oceanic constraints into atmospheric analyses and exploring the extent to which it is possible to fit both these and the bottom-up land flux estimates simultaneously; (3) improved atmospheric transport models; and (4) improved atmospheric observational constraints, of which vertical profiles and the possibility of obtaining atmospheric $\mathrm{CO}_{2}$ data from satellite observations are significant developments.

\section{Discussion and conclusions}

We have examined the atmospheric growth rate (AGR), oceanic uptake (OS), and net land carbon sink (NLS), the sum of which is required to equal the fossil fuel emissions (i.e., $\mathrm{FF}=\mathrm{AGR}+\mathrm{OS}+\mathrm{NLS}$ ). Observational and model based estimates enable us to determine three of these four variables with reasonable confidence, namely AGR, OS, and FF, from which we are able to estimate the fourth, NLS. As regards the ocean carbon sink, our comparison of the ocean uptake in four models with reanalysis climate forcing versus models with constant climate forcing led to the conclusion that oceanic uptake may have slowed relative to expectation, in agreement with previous studies (Canadell et al., 2007; Le Quéré et al., 2007; Lovenduski et al., 2007; cf. Le Quéré et al., 2009).

As regards the net land carbon sink NLS, our analysis shows that it appears to have been small between 1960 until $\sim 1988 / 1989$ (Figs. 1c and 3), with the longer-term record shown in Fig. 5 suggesting that it may have been at or near zero (the cumulative flux was nearly constant) from as early as $\sim 1930$. The net land carbon sink appears to have increased after 1988/1989. The nature of the increase is extremely difficult to detect given the short time scale of the record, the huge variability of the net land uptake estimate, and the differences between the land uptake estimates obtained with the different ocean models. Thus it is difficult for us to say whether the increase represents an abrupt shift to a higher uptake or a more gradual increase, though the cumulative NLS in Fig. 2 and LS in Fig. 6b suggest an abrupt shift is more likely.

What might have caused the net land carbon sink to increase after 1988/1989? The net land carbon sink NLS, is equal to the difference between the land sink LS and the land use source LU, i.e., with the sign convention being negative for removal from the atmosphere, NLS = LS + LU. Thus, an increase in the absolute magnitude of NLS could have been caused either by an increase in the absolute magnitude of the land sink LS or a decrease in the magnitude of the land use LU or some combination of these. Up to now we have avoided separating the time history of the net land carbon sink into its components because of the low confidence level in the land use estimates. However, as Fig. 6a shows, the land use source LU as presented in Houghton (2007) and Canadell et al. (2007) has, if anything, increased slightly in time, which implies that the increase in the absolute magnitude of the net land carbon sink NLS must be due primarily to an increase in the absolute magnitude of the land carbon sink LS (Figs. 5c and 6a and b). The only estimates of LU discussed in the review by Le Quére et al. (2009) that extend beyond our change point of 1988/1989 are the Shevliakova et al. (2009) and Houghton estimates, and neither of these shows a significant drop in the sources at anywhere near 1989, in agreement with Houghton (2007). The McGuire et al. (2001) and Van Minnen et al. (2009) results show a 

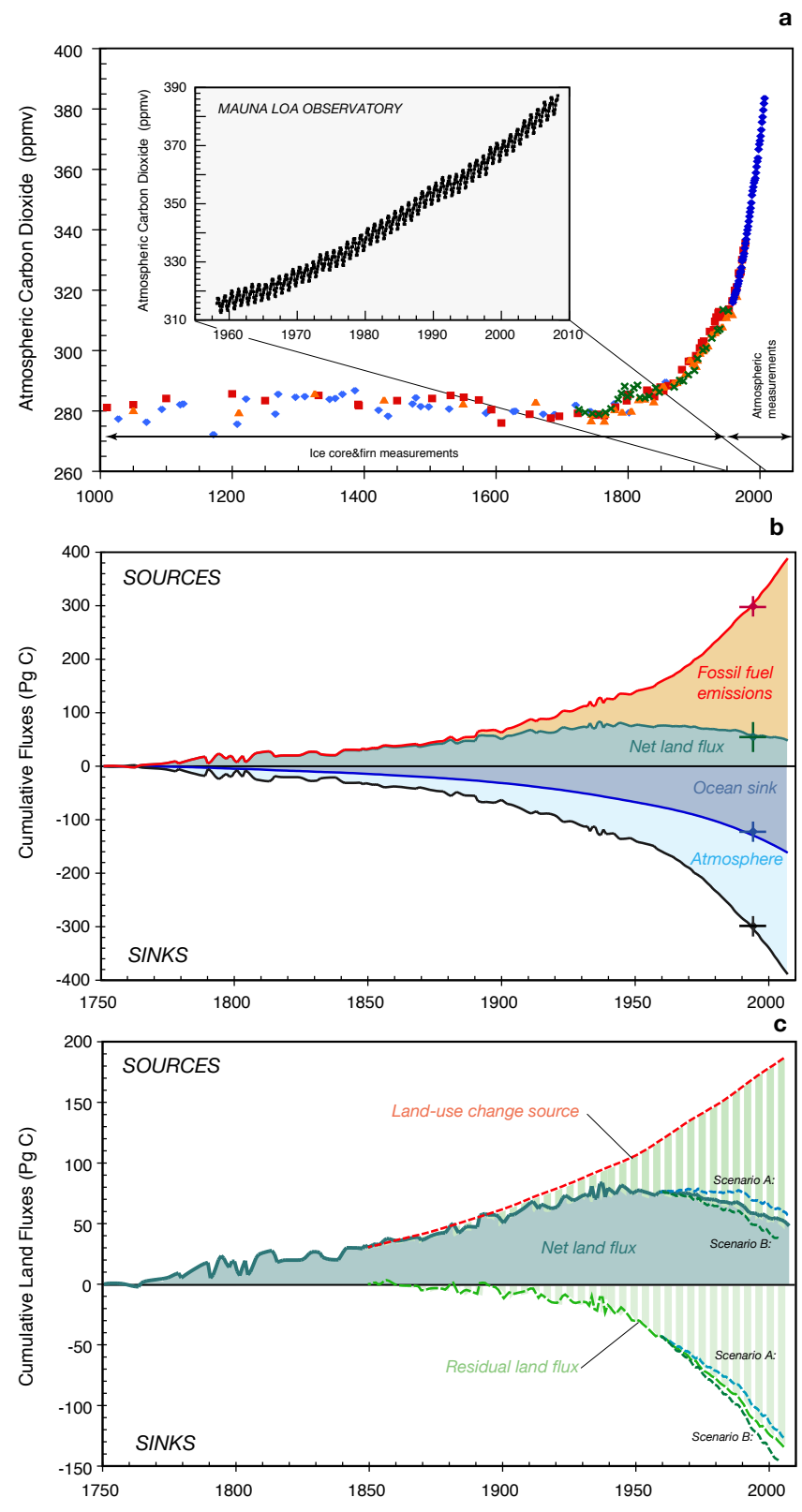

Fig. 5. Atmospheric $\mathrm{CO}_{2}$ and the cumulative carbon budget starting from 1750. Sources for data are as described in Appendix A with additional sources given in the caption. (a) Atmospheric $\mathrm{CO}_{2}$ variations over the last 1000 years. The data until 1958 stem from a series of Antarctic ice cores (Barnola, 1999), while the data from 1958 onward are from the Mauna Loa Observatory in Hawaii. The inset shows the monthly Mauna Loa measurements, whereas the main plot depicts the annual means. (b) Cumulative carbon fluxes from 1750 onwards of the main sources and sinks of the global carbon cycle including fossil fuel emissions, the atmospheric $\mathrm{CO}_{2}$ increase, ocean uptake, and net land flux. The atmospheric increase is calculated from a spline fit to the ice core and Mauna $\mathrm{Loa} \mathrm{CO}_{2}$ data from (a), the ocean uptake is based on the ocean inversion of Mikaloff Fletcher et al. (2006) scaled to the respective year assuming a linear relationship between ocean uptake and atmospheric $\mathrm{CO}_{2}$ (see Appendix A) and the net land flux is computed by the difference Net land flux = fossil fuel emissions atmospheric $\mathrm{CO}_{2}$ increase - ocean uptake. The symbols are estimates from Sabine et al. (2004) for the period from 1800 to 1994 summed to the 1790 to 1810 average of our estimates. (c) The cumulative net land flux from panel (b) (solid blue line) plus two additional scenarios for the net land flux based on the oceanic uptake estimates of Le Quéré et al. (2007; Scenario A) and Wetzel et al. (2005; Scenario B) which represent upper and lower limits of the ocean uptake estimates from Fig. 1b, respectively. Also shown in the figure is the cumulative land use source of Houghton (2007) for the period 1850 to 2005, which is summed in this figure to the 1850 net land flux. The total area under this curve including the vertically hatched green area and the solid light green area is our best estimate of the total land use change sources of $\mathrm{CO}_{2}$ to the atmosphere. The solid green area is that portion of the source that can be accounted for by the carbon budget in panel (b). The vertically hatched area thus must be balanced by the additional sinks shown in the lower part of this diagram. 

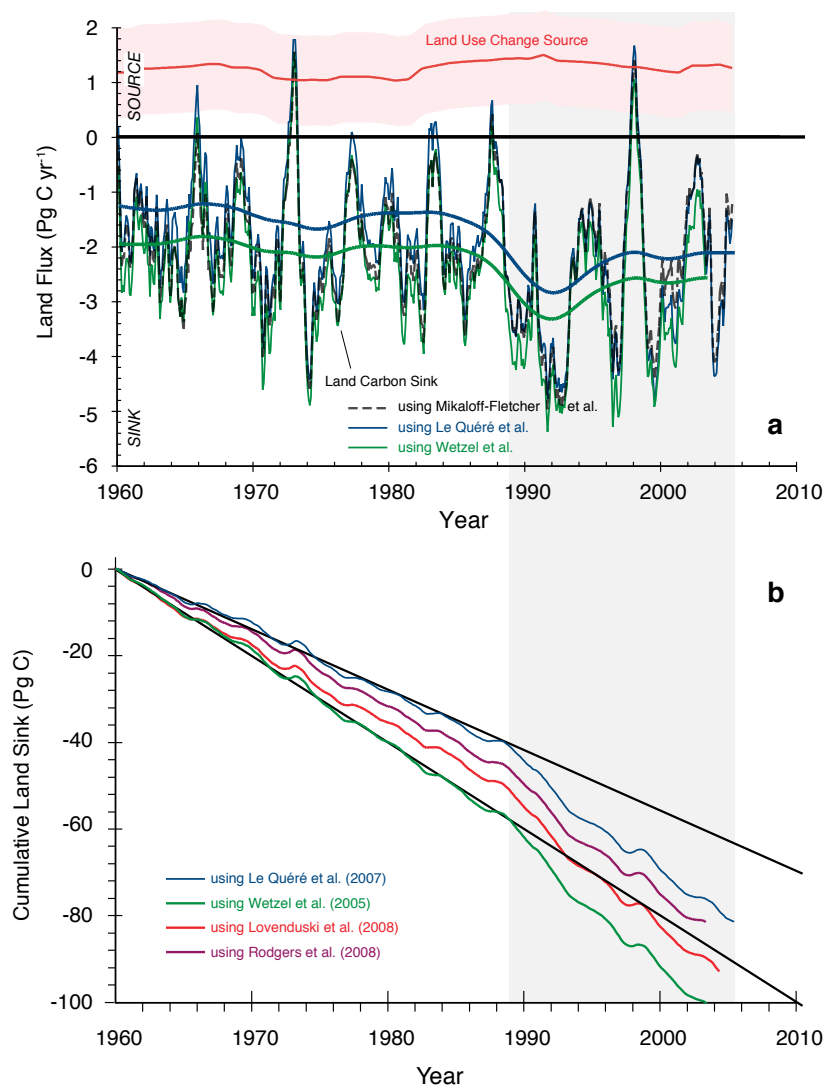

Fig. 6. (a) The annual land use change source of Houghton (2007) and the annual land carbon sink calculated as in Fig. 5 and shown from 1960 onwards. (b) The cumulative land carbon sink. The annual land carbon sink also shows smoothed lines filtered with a 5 year Butterworth filter. The straight lines in (b) are drawn in by hand to provide a guide to the eye showing that the slope increases after 1988/1989.

decrease in the land carbon sink starting ten years earlier around 1980, but the estimates end in $\sim 1992$, too early to be of use for this analysis.

What can observations and/or models tell us about the nature of the terrestrial carbon sink LS and the causes of its changes? The bottom-up carbon sink estimates of the landatmosphere carbon fluxes for the post-1988/1989 period support the results obtained by our global carbon budget estimate. A next step would be to determine if such changes can be simulated in land models that are forced with land use changes as well as reanalysis climate; and to determine if there are bottom-up observations that can tell us what was different prior to 1988/1989 and where and how the transition to a higher land uptake occurred. There are in fact several land model simulations that have been forced with reanalysis climate, though not including land use change (cf. Sitch et al., 2008). The average of five such simulations summarized by Le Quéré et al. (2009) has a similar cumulative land carbon sink as our data based estimates. However, this is presumably because the models have been tuned to fit such estimates. The land models also show a big jump in the land carbon sink, but the timing of the jump is inconsistent with ours, occurring more than a decade earlier in the mid-1970s. Moreover, the jump is attributed by Le Quéré et al. (2009) to a model error due to the overestimation of the land carbon sink response to the cool/wet La Niña-like climate conditions in the mid 1970s.

Candidates for what could be responsible for an increase in the net land carbon sink that we find include:

1. An error in the calculation of net land use due to an underestimate of pre-1988/1989 fossil fuel emissions or an overestimate of post 1988/1989 fossil fuel emissions or an error in the ocean carbon sink. The recent revisions to the fossil fuel estimates that we use in our calculations (cf. Boden et al., 2009) lowered the fossil fuel emissions by $\sim 0.2 \mathrm{Pg} \mathrm{C} \mathrm{yr}^{-1}$ after 2004 and $\sim 0.1 \mathrm{Pg} \mathrm{C} \mathrm{yr}^{-1}$ after 1993, which reduced our estimate of the increase in the land flux. Furthermore, the leveling off of the oceanic carbon sink that we showed in Fig. $1 \mathrm{~b}$ is estimated directly from ocean model simulations forced with reanalyzed meteorological observations, and supported by a modest number of observations, all of which have uncertainties as discussed in Sect. 2.3. If, for example, the post-1988/1989 leveling of ocean uptake were shown to be wrong, this would reduce our estimate of the change in the land carbon sink from -0.88 to $-0.64 \mathrm{Pg} \mathrm{C} \mathrm{yr}^{-1}$ with $p=0.02$.

2. A decrease in land use emissions, which is not supported by existing publications, as we have shown in Fig. 6.

3. A change in the land carbon sink LS due to (a) a fertilization effect such as the cumulative impact of $\mathrm{CO}_{2}$ fertilization (cf. Schimel et al., 2004); (b) growth stimulation by climate variability such as the Atlantic Multidecadal Oscillation shift in 1996 and/or the Pacific Decadal Oscillation shift in 1998, both of which come at an opportune time following the June 1991 Pinatubo eruption; (c) climate change such as the impact of the increased incidence of droughts after the mid-1980s (Trenberth et al., 2007; Buermann et al., 2007); (d) changes in solar irradiance reaching the Earth's surface, which began to increase about 20 years ago after undergoing a long period of dimming due to the impact of aerosols (Romanou et al., 2007; Weilicki et al., 2002; Trenberth et al., 2002); or (e) an increase in the growing season length due to global warming (e.g., Keeling et al., 1996).

We note that the net land carbon uptake NLS shown in Fig. 1c and the land carbon sink LS shown in Fig. 6a are highly variable in time. With such a short record, it is difficult to know if the increase in the land uptake is due to a change in the 
baseline behavior, or if it may in fact be related to changes in the variability resulting from known nonlinearities in the response of the hydrological cycle to ENSO variability in conjunction with nonlinearities in the terrestrial carbon response to variations in hydrological or other climate forcing.

We conclude that the net land carbon sink NLS appears to have increased abruptly around 1988/1989 due primarily to an increase in the land carbon sink LS. We also confirm a small reduction in the oceanic sink in models forced with reanalysis climate versus those forced with a constant climate. The difference between the increased land carbon sink and reduced ocean sink is small and uncertain, but the increase in the land uptake is larger than the reduction in the ocean uptake, implying that the atmospheric growth rate decreased over time with respect to what would have happened if the land carbon sink had continued at its pre-1988/1989 magnitude and the ocean had not changed in response to climate. Our analysis suggests that fundamental changes in the carbon cycle may be underway in both the oceans and terrestrial biosphere that pose important challenges to our mechanistic understanding of controls on carbon flux variability and trends.

\section{Appendix A}

\section{Data sources and methods}

\section{A1 Fossil fuel emissions}

Annual fossil fuel emissions from 1750 through 2006 are from Boden et al., 2009 supplemented by Marland (personal communication, 2009), who provided slightly updated 2006 emissions and estimates of the 2007 and 2008 emissions. These annual data were used directly in the analysis shown in Tables 1 and 2 as well as Figs. 2 and 5. The monthly data shown in Fig. 1a and used in producing Figs. 3 and 6 were interpolated from the annual data using the mass conserving method of Rasmussen (1991). We calculate the long-term average annual growth rate of emissions over a time interval from $t=0$ to $t=T$ following the annual mortality concept used in the ecological literature (Sheil et al., 1995). The algebraic formulation for the long-term average annual growth rate approach is

$\mathrm{FF}(T)=\mathrm{FF}(0) \cdot(1+\text { growth rate })^{T}$

where $\mathrm{FF}$ is fossil fuel emissions for a given year $t$. Inverting the above equation gives the growth rate as

growth rate $=\left(\frac{\mathrm{FF}(T)}{\mathrm{FF}(0)}\right)^{\frac{1}{T}}-1$

\section{A2 Atmospheric growth rate}

The monthly atmospheric $\mathrm{CO}_{2}$ data are obtained from the filled data set given in column 9 of http://scrippsco2.ucsd. edu/data/in_situ_co2/monthly_mlo.csv (Keeling et al., 2001). The annual growth rate of $\mathrm{CO}_{2}$ in $\mathrm{PgC}$ shown in Fig. 1a is calculated month by month for time $t$ in months using the equation

$$
\begin{aligned}
& \frac{d \mathrm{CO}_{2}}{d t}=\gamma \cdot\left[p \mathrm{CO}_{2}(t+6)-p \mathrm{CO}_{2}(t-6)\right] \\
& \gamma=2.1276 \frac{\mathrm{Pg} \mathrm{C}}{\mathrm{ppm}}
\end{aligned}
$$

where $p \mathrm{CO}_{2}$ is the atmospheric partial pressure of $\mathrm{CO}_{2}$ in ppm. The growth rate is then smoothed with a 3-months boxcar filter to remove short time scale variability. The conversion factor $\gamma$ is calculated as follows: atmospheric carbon dioxide is reported as the dry air molar mixing ratio in ppm units per year. This is converted to $\mathrm{PgC}$ of $\mathrm{CO}_{2}$ in the atmosphere using the relationships:

$$
\begin{aligned}
& N_{\text {air }}=\frac{m_{\text {atm }}}{\mu_{\text {air }}} \\
& \mu_{\text {air }}=0.0289644+0.012011 \cdot\left(\chi_{\mathrm{CO}_{2}}-0.0004\right) \\
& N_{\mathrm{CO}_{2}}=\chi_{\mathrm{CO}_{2}} \cdot N_{\text {air }} \\
& m_{\mathrm{CO}_{2}}=\mu_{\mathrm{C}} \cdot N_{\mathrm{CO}_{2}}
\end{aligned}
$$

where $N_{\text {air }}$ is the number of moles in the atmosphere, $m_{\mathrm{atm}}$ is the total dry mass of the atmosphere for which we use the estimate of $5.1352 \pm 0.0003 \times 10^{18} \mathrm{~kg}$ from Trenberth and Smith (2005), $\mu_{\text {air }}$ is the molar mass of air in $\mathrm{kg} \mathrm{mol}^{-1}$ for which we use the relationship given by Khélifa et al. (2007), $\chi_{\mathrm{CO}_{2}}$ is the dry air molar mixing ratio of carbon dioxide obtained by measurements, and $\mu_{\mathrm{C}}=12 \mathrm{~g} \mathrm{~mol}^{-1}$ is the molar mass of carbon. The conversion factor we obtain is $2.12760 \mathrm{Pg} \mathrm{C}$ per ppm of dry air in January 1960, decreasing to 2.12754 by December of 2008 . We thus use a conversion factor $\gamma$ of $2.1276 \mathrm{Pg} \mathrm{C}$ per ppm of dry air.

The annual atmospheric $\mathrm{CO}_{2}$ growth rate used in Tables 1 and 2 and Figs. 2 and 5 is calculated by taking the difference between the December and January mean at the end of the year minus the December and January mean at the start of the year multiplied by the conversion factor $\gamma$.

\section{A3 Ocean uptake}

The Le Quéré et al. (2007), Lovenduski et al. (2008), Rodgers et al. (2008) and Wetzel et al. (2005) monthly uptake results are from "hindcast" simulations using the daily mean (except Lovenduski et al., who use 6-h mean) NCEP1 Kalnay et al. (1996) reanalysis winds, and freshwater and heat fluxes as described in each of the papers. All models include seasonality. Annual means used in the Tables 1 and 2 and Fig. 3 calculations are obtained by taking the average of the monthly results. The monthly ocean uptake results shown in Fig. 1b and used for the net land uptakes in Fig. 1c have been deseasonalized and smoothed with a 3 month boxcar filter using the same approach as with the atmospheric growth rate. 
The Mikaloff Fletcher et al. (2006) ocean uptake is estimated using their equation

$$
\mathrm{OS}=-2.15 \cdot \frac{p \mathrm{CO}_{2}-277.9514 \mathrm{ppm}}{359.6619 \mathrm{ppm}-277.9514 \mathrm{ppm}} \mathrm{Pg} \mathrm{C} \mathrm{yr}^{-1}
$$

where $p \mathrm{CO}_{2}$ is the atmospheric $\mathrm{CO}_{2}$ in ppm of dry air. The annual oceanic uptake is calculated using the annual average atmospheric Mauna Loa $p \mathrm{CO}_{2}$, and the monthly uptake is estimated using the deseasonalized and smoothed monthly Mauna Loa atmospheric $p \mathrm{CO}_{2}$ data.

Only the Le Quéré et al. (2007) model has been run out to the full length of time of our analysis in 2007. The Wetzel et al. (2005) and Rodgers et al. (2008) simulations were run out to 2003, and the Lovenduski et al. (2008) simulation was run out to 2004. Because the oceanic uptake is relatively flat after 1990, the post-1988/1989 ocean uptake averages given in Table 2 are relatively insensitive to the averaging interval used. We present the average of all models until the most recent full year of each simulation, which varies from 2003 to 2007.

None of the ocean or net land uptake calculations shown in this paper include the weathering and river flux contribution of $\sim 0.45 \mathrm{PgC}^{-1}$, which should be subtracted from the net land uptake (thereby increasing the land uptake) and added to the ocean uptake (thereby decreasing the ocean uptake) for comparison with observations (cf. Jacobson et al., 2007a)

Acknowledgements. We thank G. Marland for providing his most recent estimates of fossil fuel emission and J. Simeon for help on data analysis. We greatly appreciate helpful comments received on very early versions of this manuscript from Oliver Phillips as well as M. Bender, R. Keeling, C. Le Quéré, B. Mignone, M. Oppenheimer, D. Sigman, and R. Wanninkhof. The work of JLS on the global carbon cycle has been supported by the Department of Energy under a NICCR proposal, by the NOAA Geophysical Fluid Dynamics Laboratory and Earth System Research Laboratory, which also supported SMF, and the Carbon Mitigation Initiative with support from the Ford Motor Company and by BP, which also supported SP and KR. MG was supported by the EBI and EEE institutes at the University of Leeds, and NG by ETH Zurich. CB was supported by the Fonds Québécois de la recherche sur la nature et les technologies and by the Carbon Mitigation Initiative.

Edited by: J. Middelburg

\section{References}

Achard, F., Eva, H. D., Stibig, H.-J., Mayaux, P., Gallego, J., Richards, T., and Malingreau, J.-P.: Determination of deforestation rates of the World's humid tropical forests, Science, 297, 999-1002, 2002.

Achard, F., Eva, H. D., Mayaux, P., Stibig, H.-J., and Belward, A.: Improved estimates of net carbon emissions from land cover change in the tropics for the 1990s, Global Biogeochem. Cy., 18, GB2008, doi:10.1029/2003GB002142, 2004.

Baker, D. F., Law, R. M., Gurney, K. R., Rayner, P., Peylin, P., Denning, A. S., Bousquet, P., Bruhwiler, L., Chen, Y.
H., Ciais, P., Fung, I. Y., Heimann, M., John, J., Maki, T., Maksyutov, S., Masarie, K., Prather, M., Pak, B., Taguchi, S., and Zhu, Z.: TransCom 3 inversion intercomparison: Impact of transport model errors on the interannual variability of regional $\mathrm{CO}_{2}$ fluxes, 1988-2003, Global Biogeochem. Сy., 20, doi:10.1029/2004GB002439, GB1002, 2006.

Barford, C. C., Wofsy, S. C., Goulden, M. L., Munger, J. W., Pyle, E. H., Urbanski, S. P., Hutyra, L., Saleska, S. R., Fitzjarrald, D., and Moore, K.: Factors controlling long- and short-term sequestration of atmospheric $\mathrm{CO}_{2}$ in a mid-latitude forest, Science, 294, 1688-1691, 2001.

Barnola, J. M.: Status of the atmospheric $\mathrm{CO}_{2}$ reconstruction from ice core analyses, Tellus B, 51, 151-155, 1999.

Bates, N. R.: Interannual variability of the oceanic $\mathrm{CO}_{2}$ sink in the subtropical gyre of the North Atlantic Ocean over the last 2 decades, J. Geophys. Res., 112, C09013, doi:10.1029/2006JC003759, 2007.

Battle, M., Bender, M. L., Tans, P. P., White, J. W. C., Ellis, J. T., Conway, T., and Francey, R. J.: Global carbon sinks and their variability inferred from atmospheric $\mathrm{O}_{2}$ and $\delta^{13} \mathrm{C}$, Science, 287, 2467-2470, 2000.

Bender, M. L., Ho, D. T., Hendricks, M. B., Mika, R., Battle, M. O., Tans, P. P., Conway, T. J., Sturtevant, B., and Cassar, N.: Atmospheric $\mathrm{O}_{2} / \mathrm{N}_{2}$ changes, 1993-2002: Implications for the partitioning of fossil fuel $\mathrm{CO}_{2}$ sequestration, Global Biogeochem. Cy., 19, GB4017, doi:10.1029/2004GB002410, 2005.

Boden, T. A., Marland, G., and Andres, R. J.: Global, regional, and national $\mathrm{CO}_{2}$ emissions, in: http://cdiac.ornl.gov/trends/emis/ tre_glob.html last access: July 2009, Carbon Dioxide Information Analysis Center, Oak Ridge National Laboratory, Oak Ridge, 2009.

Böning, C. W., Dispert, A., Visbeck, M., Rintoul, S. R., and Schwarzkopf, F. U.: The response of the Antarctic Circumpolar Current to recent climate change, Nat. Geosci., 1, 864-869, doi:10.1038/ngeo362, 2008.

Broecker, W. S., Takashashi, T., Simpson, H. J., and Peng, T. H.: Fate of fossil fuel carbon dioxide and the global carbon budget, Science, 206, 409-418, 1979.

Buermann, W., Lintner, B. R., Koven, C. D., Angert, A., Pinzon, J. E., Tucker, C. J., and Fung, I. Y.: The changing carbon cycle at Mauna Loa Observatory, P. Natl. Acad. Sci. USA, 104, 42494254, 2007.

Canadell, J. G., Le Quéré, C., Raupach, M. R., Field, C. B., Buitenhuis, E. T., Ciais, P., Conway, T. J., Gillett, N. P., Houghton, R. A., and Marland, G.: Contributions to accelerating atmospheric $\mathrm{CO}_{2}$ growth from economic activity, carbon intensity, and efficiency of natural sinks, P. Natl. Acad. Sci. USA, 104, 1886618870, 2007.

Chave, J., Condit, R., Muller-Landau, H. C., Thomas, S. C., Ashton, P. S., Bunyavejchewin, S., Co, L. L., Dattaraja, H. S., Davies, S. J., Esufali, S., Ewango, C. E. N., Feeley, K. J., Foster, R. B., Gunatilleke, N., Gunatilleke, S., Hall, P., Hart, T. B., Hernández, C., Hubbell, S. P., Itoh, A., Kiratiprayoon, S., LaFrankie, J. V., Lao, S. L. D., Makana, J.-R., Noor, M. N. S., Kassim, A. R., Samper, C., Sukumar, R., Suresh, H. S., Tan, S., Thompson, J., Tongco, M. D. C., Valencia, R., Vallejo, M., Villa, G., Yamakura, T., Zimmerman, J. K., and Losos, E. C.: Assessing evidence for pervasive alteration in tropical tree communities, PLOS Biol., 6, e45, doi:10.1371/journal.pbio.0060045, 2008. 
Chen, G. and Held, I. M.: Phase speed spectra and the recent poleward shift of southerrn hemisphere surface westerlies, Geophys. Res. Lett., 34, L21805, doi:10.1029/2007GL031200, 2007.

DeFries, R. S., Houghton, R. A., Hansen, M. C., Field, C. B., Skole, D., and Townshend, J.: Carbon emissions from tropical deforestation and regrowth based on satellite observations for the 1980s and 1990s, P. Natl. Acad. Sci. USA, 99, 14256-14261, 2002.

Denman, K., Brasseur, G., Chidthaison, A., Ciais, P., Cox, P. M., Dickinson, R. E., Hauglustaine, D., Heinze, C., Holland, E., Jacob, D., Lohmann, U., Ramachandran, S., da Silva Dias, P. L., Wofsy, S. C., and Zhang, X.: Couplings between changes in the climate system and biogeochemistry, in: Climate Change 2007: The Physical Science Basis. Contribution of Working Group I to the Fourth Asessment Report of the Intergovernmental Panel on Climate Change, edited by: Solomon, S., Qin, D., Manning, M., Chen, Z., Marquis, M., Avery, K. B., Tignor, M., and Miller, H. L., Cambridge University Press, New York, 2007.

Doney, S. C., Lima, I., Feely, R. A., Glover, D. M., Lindsay, K., Mahowald, N., Moore, J. K., and Wanninkhof, R.: Mechanisms governing interannual variability in upper-ocean inorganic carbon system and air-sea $\mathrm{CO}_{2}$ fluxes: Physical climate and atmospheric dust: Deep-Sea Res. Pt. I, 56, 640-655, 2009.

Dore, J. E., Lukas, R., Sadler, D. W., Church, M. J., and Karl, D. M.: Physical and Biogeochem. modulation of ocean acidification in the central North Pacific, P. Natl. Acad. Sci. USA, 106, 1223512240, 2009.

Fearnside, P.: Global warming and tropical land-use change: greenhouse gas emissions from biomass burning, decomposition and soils in forest conversion, shifting cultivation and secondary vegetation, Climatic Change, 46, 115-158, 2000.

Feely, R. A., Takahashi, T., Wanninkhof, R., McPhaden, M. J., Cosca, C. E., Sutherland, S. C., and Carr, M.-E.: Decadal variability of the air-sea $\mathrm{CO}_{2}$ fluxes in the equatorial Pacific Ocean, J. Geophys. Res., 111, C08S90, doi:10.1029/2005JC003129, 2006.

Food and Agriculture Organization: Global Forest Resources Assessment 2000 main report, FAO For. Pap. 140, Rome, 479, 2001.

Gloor, M., Sarmiento, J. L., and Gruber, N.: What can be learned about carbon cycle climate feedbacks from $\mathrm{CO}_{2}$ airborne fraction?, Atmos. Chem. Phys., in press, 2010.

Goodale, C. L., Apps, M. J., Birdsey, R. A., Field, C. B., Heath, L. S., Houghton, R. A., Jenkins, J. C., Kohlmaier, G. H., Kurz, W., Liu, S. R., Nabuurs, G. J., Nilsson, S., and Shvidenko, A. Z.: Forest carbon sinks in the Northern Hemisphere, Ecol. Appl., 12, 891-899, 2002.

Grainger, A.: Difficulties in tracking the long-term global trend in tropical forest area, P. Natl Acad. Sci. USA, 105, 818-823, 2008.

Gruber, N., Keeling, C. D., and Bates, N. R.: Interannual variability in the North Atlantic ocean carbon sink, Science, 298, 23742378, 2002.

Gruber, N., Gloor, M., Fletcher, S. E. M., Doney, S. C., Dutkiewicz, S., Follows, M. J., Gerber, M., Jacobson, A. R., Joos, F., Lindsay, K., Menemenlis, D., Mouchet, A., Müller, S. A., Sarmiento, J. L., and Takahashi, T.: Oceanic sources, sinks, and transport of atmospheric $\mathrm{CO}_{2}$, Global Biogeochem. Cy., 23, GB1005, doi:1010.1029/2008GB003349, 2009.

Gu, L., Baldocchi, D. D., Wofsy, S. C., Munger, J. W., Michalsky, J. J., Urbanski, S. P., and Boden, T. A.: Response of a deciduous forest to the Mount Pinatubo eruption: enhanced photosynthesis,
Science, 299, 2035-2038, 2003.

Gurney, K. R., Law, R. M., Denning, A. S., Rayner, P. J., Pak, B. C., Baker, D., Bousquet, P., Bruhwiler, L., Chen, Y.-H., Ciais, P., Fung, I. Y., Heimrann, M., John, J., Maki, T., Maksyutov, S., Peylin, P., Prather, M., and Taguchi, S.: Transcom 3 inversion intercomparison: Model mean results for the estimation of seasonal carbon sources and sinks, Global Biogeochem. Cy., 18, GB1010, doi:10.1029/2003GB002111, 2004.

Hallberg, R. W. and Gnanadesikan, A.: The role of eddies in determining the structure and response of the wind-driven southern hemisphere overturning: Results from the Modeling Eddies in the Southern Ocean (MESO) Project, J. Phys. Oceanogr., 36, 2232-2252, 2006.

Houghton, R. A.: Why are estimates of the terrestrial carbon balance so different?, Global Change Biol., 9, 500-509, 2003.

Houghton, R. A.: Balancing the global carbon budget, Annu. Rev. Earth Pl. Sc., 35, 313-347, 2007.

Jacobson, A. R., Fletcher, S. E. M., Gruber, N., Sarmiento, J. L., and Gloor, M.: A joint atmosphere-ocean inversion for surface fluxes of carbon dioxide: 2. Regional results, Global Biogeochem. Сy., 21, GB1020, doi:10.1029/2006GB002703, 2007a.

Jacobson, A. R., Mikaloff Fletcher, S. E., Gruber, N., Sarmiento, J. L., and Gloor, M.: A joint atmosphere-ocean inversion for surface fluxes of carbon dioxide: 1. Methods and global-scale fluxes, Global Biogeochem. Cy., 21, GB1019, doi:10.1029/2005GB002556, 2007b.

Jones, C. D. and Cox, P. M.: Modeling the volcanic signal in the atmospheric $\mathrm{CO}_{2}$ record, Global Biogeochem. Cy., 15, 453-465, 2001.

Jung, M., Reichstein, M., and Bondeau, A.: Towards global empirical upscaling of FLUXNET eddy covariance observations: validation of a model tree ensemble approach using a biosphere model, Biogeosciences, 6, 2001-2013, doi:10.5194/bg-6-20012009, 2009.

Kalnay, E., Kanamitsu, M., Kistler, R., Collins, W., Deaven, D., Gandin, L., Iredell, M., Saha, S., White, G., Woollen, J., Zhu, Y., Chelliah, M., Ebisuzaki, W., Higgins, W., Janowiak, J., Mo, K. C., Ropelewski, C., Wang, J., Leetmaa, A., Reynolds, R., Jenne, R., and Joseph, D.: The NCEP/NCAR 40-year reanalysis project, B. Am. Meteorol. Soc., 77, 437-471, 1996.

Keeling, C. D., Chin, J. F. S., and Whorf, T. P.: Increased activity of northern vegetation inferred from atmospheric $\mathrm{CO}_{2}$ measurements, Nature, 382, 146-149, 1996.

Keeling, C. D., Piper, S. C., Bacastow, R. B., Wahlen, M., Whorf, T. P., Heimann, M., and Meijer, H. A.: Exchanges of amospheric $\mathrm{CO}_{2}$ and ${ }^{13} \mathrm{CO}_{2}$ with the terrestrial biosphere and oceans from 1978 to 2000, I. Global aspects, Scripps Institution of Oceanography, San Diego SIO Reference Series, No. 01-06, 88, 2001.

Keeling, C. D., Brix, H., and Gruber, N.: Seasonal and longterm dynamics of the upper ocean carbon cycle at Station ALOHA near Hawaii, Global Biogeochem. Cy., 18, GB4006, doi:10.1029/2004GB002227, 2004.

Khélifa, N., Lecollinet, M., and Himbert, M.: Molar mass of dry air in mass metrology, Measurement, 40, 779-784, 2007.

Lenton, A., Codron, F., Bopp, L. N., Metzl, P. C., Tagliabue, A., and Le Sommer, J.: Stratospheric ozone depletion reduces ocean carbon uptake and enhances ocean acidification, Geophys. Res. Lett., 36, L12606, doi:10.1029/20009GL038227, 2009.

Le Quéré, C., Raupach, M. R., Canadell, J. G., Marland, G., Bopp, 
L., Ciais, P., Conway, T. J., Doney, S. C., Feely, R. A., Foster, P., Friedlingstein, P., Gurney, K., Houghton, R. A., House, J. I., Huntingford, C., Levy, P. E., Lomas, M. R., Majkut, J., Metzl, N., Ometto, J. P., Peters, G. P., Prentice, I. C., Randerson, J. T., Running, S. W., Sarmiento, J. L., Schuster, U., Sitch, S., Takahashi, T., Viovy, N., von der Werf, G. R., and Woodward, F. I.: Trends in the sources and sinks of carbon dioxide, Nat. Geosci., 2, 831-836, doi:10.1038/ngeo689, 2009.

Le Quéré, C., Rödenbeck, C., Buitenhuis, E. T., Conway, T. J., Langenfelds, R., Gomez, A., Labuschagne, C., Ramonet, M., Nakazawa, T., Metzl, N., Gillett, N., and Heimann, M.: Saturation of the Southern Ocean $\mathrm{CO}_{2}$ sink due to recent climate change, Science, 316, 1735-1738, 2007.

Lewis, S. L., Lopez-Gonzalez, G., Sonké, B., Affum-Baffoe, K., Baker, T. R., Ojo, L. O., Phillips, O. L., Reitsma, J. M., White, L., James, A., Comiskey, K. M.-N. D., Ewango, C. E. N., Feldpausch, T. R., Hamilton, A. C., Gloor, M., Hart, T., Hladik, A., Lloyd, J., Lovett, J. C., Makana, J.-R., Malhi, Y., Mbago, F. M., Ndangalasi, H. J., Peacock, J., Peh, K. S.-H., Sheil, D., Sunderland, T., Swaine, M. D., Taplin, J., Taylor, D., Thomas, S. C., and Wöll, R. V. H.: Increasing carbon storage in intact African tropical forests, Nature, 457, 1003-1006, 2009.

Lovenduski, N. S., Gruber, N., Doney, S. C., and Lima, I. D.: Enhanced $\mathrm{CO}_{2}$ outgassing in the Southern Ocean from a positive phase of the Southern Annular Mode, Global Biogeochem. Cy., 21, GB2026, doi:10.1029/2006GB002900, 2007

Lovenduski, N. S., Gruber, N., and Doney, S. C.: Towards a mechanistic understanding of the decadal trends in the Southern Ocean carbon sink, Global Biogeochem. Cy., 22, GB3016, doi:3010.1029/2007GB003139, 2008.

Malhi, Y., Roberts, J. T., Betts, R. A., Killeen, T. J., Li, W., and Nobre, C. A.: Climate change, deforestation, and the fate of the Amazon, Science, 319, 169-172, 2008.

Manning, A. C. and Keeling, R. F.: Global oceanic and land biotic carbon sinks from the Scripps atmospheric oxygen flask sampling network, TellusB , 58, 95-116, 2006.

Marland, G.: Uncertainties in accounting for $\mathrm{CO}_{2}$ from fossil fuels, J. Ind. Ecol., 12, 136-139, 2008.

McGuire, A. D., Sitch, S., Clein, J. S., Dargaville, R., Esser, G., Foley, J., Heimann, M., Joos, F., Kaplan, J., Kicklighter, D. W., Meier, R. A., Melillo, J. M., Moore, B., Prentice, I. C., Ramankutty, N., Reichenau, T., Schloss, A., Tian, H., Williams, L. J., and Wittenberg, U.: Carbon balance of the terrestrial biosphere in the twentieth century: Analyses of $\mathrm{CO}_{2}$, climate and land use effects with four process-based ecosystem models: Global Biogeochemical Cy., 15, 183-206, 2001.

Mikaloff Fletcher, S. E., Gruber, N., Jacobson, A. R., Doney, S. C., Dutkiewicz, S., Follows, M., Lindsay, K., Menemenlis, D., Mouchet, A., and Sarmiento, J. L.: Inverse estimates of anthropogenic $\mathrm{CO}_{2}$ uptake, transport, and storage by the ocean, Global Biogeochem. Cy., 20, GB2002, doi:10.1029/2005GB002530, 2006.

Pacala, S., Birdsey, R., Bridgham, S., Conant, R. T., Davis, K., Hales, B., Houghton, R., Jenkins, J. C., Johnston, M., Marland, G. H., and Paustian, K.: The North American carbon budget past and present, in: The First State of the Carbon Cycle Report (SOCCR): North American Carbon Budget and Implications for the Global Carbon Cycle, A report by the US Climate Change Science Program and the Subcommittee on Global Change Re- search, edited by: King, A. W. L. D. G. P. Z., Fairman, D. M., Houghton, R. A., Marland, G. H., Rose, A. Z., and Wilbanks, T. J., National Ocean and Atmospheric Administration, Climate Program Office, Silver Spring, MD, USA, 2007.

Peylin, P., Bousquet, P., Le Quéré, C., Sitch, S., Friedlingstein, P., McKinley, G. A., Gruber, N., Rayner, P., and Ciais, P.: Multiple constraints on regional $\mathrm{CO}_{2}$ flux variations over land and oceans, Global Biogeochem. Cy., 19, GB1011, doi:10.1029/2003GB002214, 2005.

Phillips, O. L., Malhi, Y., Higuchi, N., Laurance, W. F., Nunez, P. V., Vasquez, R. M., Laurance, S. G., Ferreira, L. V., Stern, M., Brown, S., and Grace, J.: Changes in the carbon balance of tropical forests: Evidence from long-term plots, Science, 282, 439-442, 1998.

Phillips, O. L., Aragão, L. E. O. C., Lewis, S. L., Fisher, J. B., Lloyd, J., López-González, G., Malhi, Y., Monteagudo, A., Peacock, J., Quesada, C. A., von der Heijden, G., Almeida, S., Amaral, I., Arroyo, L., Aymard, G., Baker, T. R., Bánki, O., Blanc, L., Bonal, D., Brando, P., Chave, J., de Oliveira, Á. C. A., Cardozo, N. D., Czimczik, C. I., Feldpausch, T. R., Freitas, M. A., Gloor, E., Higuchi, N., Jiménez, E., Lloyd, G., Meir, P., Mendoza, C., Morel, A., Neill, D. A., Nepstad, D., Patiño, S., Peñuela, M. C., Prieto, A., Ramírez, F., Schwarz, M., Silva, J., Silveira, M., Thomas, A. S., Steege, H. T., Stropp, J., Vásquez, R., Zelazowski, P., Dávila, E. A., Andelman, S., Andrade, A., Chao, K.-J., Erwin, T., Fiore, A. D. C. , Keeling, E. H., Killeen, H., William, T. J., Laurance, F., Cruz, A. P., Pitman, N. C. A., Vargas, P. N., Ramírez-Angulo, H., Rudas, A., Salamão, R., Silva, N., Terborgh, J., and Torres-Lezama, A.: Drought sensitivity of the Amazon rainforest, Science, 323, 1344-1347, 2009.

Rasmussen, L. A.: Piecewise integral splines of low degree, Comput. Geosci., 17, 1255-1263, 1991.

Raupach, M. R., Marland, G., Ciais, P., Le Quéré, C., Canadell, J. G., Klepper, G., and Field, C. B.: Global and regional drivers of accelerating $\mathrm{CO}_{2}$ emissions, P. Natl. Acad. Sci. USA, 104, 10288-10293, 2007.

Roderick, M. L., Farquhar, G. D., Berry, S. L., and Noble, I. R.: On the direct effect of clouds and atmospheric particles on the productivity and structure of vegetation, Oecologia, 129, 21-30, 2001.

Rodgers, K. B., Sarmiento, J. L., Aumont, O., Crevoisier, C., Montegut, C. d. B., and Metzl, N.: A wintertime uptake window for anthropogenic $\mathrm{CO}_{2}$ in the North Pacific, Global Biogeochem. Cy., 22, GB2020, doi:10.1029/2006GB002920, doi:10.1029/2006GB002910, 2008.

Romanou, A., Liepert, B., Schmidt, G. A., Rossow, W. B., Ruedy, R. A., and Zhang, Y.: 20th century changes in surface solar irradiance in simulations and observations, Geophys. Res. Lett., 34, L05713, doi:10.1029/20036GL028356, 2007.

Sabine, C. L., Feely, R. A., Gruber, N., Key, R. M., Lee, K., Bullister, J. L., Wannikhof, R., Wong, C. S., Wallace, D. W. R., Tilbrook, B., Millero, F. J., Peng, T.-H., Kozyr, A., Ono, T., and Rios, A. F.: The oceanic sink for anthropogenic $\mathrm{CO}_{2}$, Science, 305, 367-371, 2004.

Schimel, D., Melillo, J., Tian, H., Rosenbloom, N., Running, S., Thornton, P., Ojima, D., Parton, W., Kelly, R., Sykes, M., Neilson, R., and Rizzo, B.: Contribution of increasing $\mathrm{CO}_{2}$ and climate to carbon storage by ecosystems in the United States, Science, 287, 2004-2006, 2004. 
Schimel, D. S., House, J. I., Hibbard, K. A., Bousquet, P., Ciais, P., Peylin, P., Braswell, B. H., Apps, M. J., Baker, D., Bondeau, A., Canadell, J., Churkina, G., Cramer, W., Denning, A. S., Field, C. B., Friedlingstein, P., Goodale, C., Heimann, M., Houghton, R. A., Melillo, J. M., Moore III, B., Murdiyarso, D., Noble, I., Pacala, S. W., Prentice, I. C., Raupach, M. R., Rayner, P., Scholes, R. J., Steffen, W. L., and Wirth, C.: Recent patterns and mechanisms of carbon exchange by terrestrial ecosystems, Nature, 414, 169-172, 2001.

Schuster, U. and Watson, A. J.: A variable and decreasing sink for atmospheric $\mathrm{CO}_{2}$ in the North Atlantic, J. Geophys. Res., 112, C11006, doi:10.1029/2006JC003941, 2007.

Sheil, D., Burslem, D. F. R. P., and Alder, D.: The interrpetation and misinterprtation of mortality rate measurements, J. Ecol., 83, 331-333, 1995.

Shevliakova, E., Pacala, S. W., Malyshev, S., Hurtt, G. C., Milly, P. C. D., Caspersen, J. P., Sentman, L. T., Fisk, J. P., Wirth, C., and Crevoisier, C.: Carbon cycling under 300 years of land use change: Importance of the secondary vegetation sink, Global Biogeochem. Cy., 23, GB2022, doi:2010.1029/2007/GB003176, 2009.

Sitch, S., Huntingford, C., Gedney, N., Levy, P. E., Lomas, M., Piao, S. L., Betts, R., Ciais, P., Cox, P., Friedlingstein, P., Jones, C. D., Prentice, I. C., and Woodward, F. I.: Evaluation of the terrestrial carbon cycle, future plant geography and climate-carbon cycle feedbacks using five Dynamic Global Vegetation Models (DGVMs): Global Change Biol., 14, 2015-2039, 2008.

Stephens, B. B., Gurney, K. R., Tans, P. P., Sweeney, C., Peters, W., Bruhwiler, L., Ciais, P., Ramonet, M., Bousquet, P., Nakazawa, T., Aoki, S., Machida, T., Inoue, G., Vinnichenko, N., Lloyd, J., Jordan, A., Heimann, M., Shivistova, O., Langenfelds, R. L., Steele, L. P., Francey, R. J., and Denning, A. S.: Weak northern and strong tropical land carbon uptake from vertical profiles of atmospheric $\mathrm{CO}_{2}$, Science, 316, 1732-1735, 2007.

Takahashi, T., Sutherland, S. C., Feely, R. A., and Wanninkhof, R.: Decadal change of the surface water $p \mathrm{CO}_{2}$ in the North Pacific: A synthesis of 35 years of observations, J. Geophys. Res., 111, C07S05, doi:10.1029/2005JC003074, 2006.
Takahashi, T., Sutherland, S. C., Wanninkhof, R., Sweeney, C., Feely, R. A., Chipman, D. W., Hales, B., Friederich, G., Chavez, F., Sabine, C., Watson, A., Bakker, D. C. E., Schuster, U., Metzl, N., Yoshikawa-Inoue, H., Ishii, M., Midorikawa, T., Nojiri, Y., Körtzinger, A., Steinhoff, T., Hoppema, M., Olafsson, J., Arnarson, T. S., Tilbrook, B., Johannessen, T., Olsen, A., Bellerby, R., Wong, C. S., Delille, B., Bates, N. R., and de Baar, H. J. W.: Climatological mean and decadal change in surface ocean $p \mathrm{CO}_{2}$, and net sea-air $\mathrm{CO}_{2}$ flux over the global oceans, Deep-Sea Res. Pt. II, 49, 1601-1622, 2009.

Thompson, D. W. J. and Solomon, S.: Interpretation of recent southern hemisphere climate change, Science, 296, 895-899, 2002.

Trenberth, K. E., Jones, P. D., Ambenje, P., Bojariu, R., Easterling, D., Tank, A. K., Parker, D., Rahimzadeh, F., Renwick, J. A., Rusticucci, M., Soden, B., and Zhai, P.: Observations: Surface and atmospheric climate change, in: Contribution of Working Group I to the Fourth Assessment Report of the Intergovernmental Panel on Climate Change, edited by: Solomon, S., Qin, D., Manning, M., Chen, Z., Marquis, M., Averyt, K. B., Tignor, M., and Miller, H. L., Cambridge University Press, Cambridge, 2007.

Trenberth, K. E. and Smith, L.: The mass of the atmosphere: A constraint on global analyses, J. Climate, 18, 864-875, 2005.

Trenberth, K., Wielicki, B., Del Genio, A., Wong, T., Chen, J., Carlson, B., Allan, R., Robertson, F., Jacobowitz, H., and Slingo, A.: Changes in tropical clouds and radiation, Science, 296, 2095, 2002.

Van Minnen, J. G., Goldewijk, K. K., Stehfest, E., Eickhout, B., van Drecht, G., and Leemans, R.: The importance of three centuries of land-use change for the global and terrestrial carbon cycle, Climate Change, 97, 123-144, doi:10.1007/s10584-009-95960$0,2009$.

Wetzel, P., Winguth, A., and Maier-Reimer, E.: Sea-to-air $\mathrm{CO}_{2}$ flux from 1948 to 2003: A model study, Global Biogeochem. Cy., 19, GB2005, doi:10.10.29/2004GB002339, 2005.

Wielicki, B. A., Wong, T. M., Allan, R. P., Slingo, A., Kiehl, J. T., Soden, B. J., Gordon, C. T., Miller, A. J., Yang, S. K., Randall, D. A., Robertson, F., Susskind, J., and Jacobowitz, H.: Evidence for large decadal variability in the tropical mean radiative energy budget, Science, 295, 841-844, 2002. 